\title{
Article \\ The Covenants of the Prophet and the Problems of Transmission: An Analysis of a Manuscript Copied by Fāris al-Shidyāq
}

\author{
John Andrew Morrow
}

Citation: Morrow, John Andrew. 2021. The Covenants of the Prophet and the Problems of Transmission: An Analysis of a Manuscript Copied by Fāris al-Shidyāq. Religions 12: 751 . https://doi.org/10.3390/rel12090751

Academic Editor: Susanne Olsson

Received: 28 June 2021

Accepted: 18 August 2021

Published: 11 September 2021

Publisher's Note: MDPI stays neutral with regard to jurisdictional claims in published maps and institutional affiliations.

Copyright: (C) 2021 by the author. Licensee MDPI, Basel, Switzerland. This article is an open access article distributed under the terms and conditions of the Creative Commons Attribution (CC BY) license (https:// creativecommons.org/licenses/by/ $4.0 /)$.
Department of Foreign Languages, Ivy Tech Community College, Fort Wayne, IN 46805, USA; John.Morrow@covenantsoftheprophet.org

\begin{abstract}
This study examines a covenant of the Prophet, namely, a treaty, patent of protection or charter of privileges, that was copied by Fāris al-Shidyāq at some time before the middle of the nineteenth century. It provides a biographical sketch of the copyist. It reproduces the Arabic original as found in Majmū' faw $\bar{a}^{\prime} i d$ along with an English translation. This is followed by a commentary on the covenant and a series of conclusions, namely, that the "Shidyāq Covenant" from 1857 is a copy of the "Rylands Covenant," which appears to be an Ottoman-issued document dating from the sixteenth or seventeenth century. This "Shidyāq/Rylands Covenant" could represent the missing link between the "Covenant of the Prophet Muhammad with the Christians of Najrān," found in the Chronicle of Seert, and the "Covenant of the Prophet Muhammad with the Christians of the World," namely, the Testamentum et Pactiones made famous by Gabriel Sionita in 1630. The significance of this study resides in the fact that it shares a previously unpublished and unstudied covenant of the Prophet Muhammad, in both Arabic and English, with the scholarly community, while exploring the problems posed by transmission. The more covenants that are rediscovered, the better we will understand their origin, diffusion, and relationship, allowing us to better assess their authenticity. What is more, if these documents are accepted by Muslims as authentic, either in word or in spirit, they can help counter and prevent radicalization, promote moderation, and help protect minorities.
\end{abstract}

Keywords: Ahmmad Fāris al-Shidyāq; Covenants of the Prophet Muhammad; Mu'āwiyah; 'Alī ibn Abī Ṭālib; Rashīd Daḥdāḥ; Ibrahim Mohamed Zein; Ahmed El-Wakil; Jeanne Aubert; William Scawen Blunt; Chronicle of Seert; Treaty of Najrān; religious pluralism; John Rylands Library

\section{Introduction and Methodology}

The Bibliothèque universitaire des langues et civilisations (BULAC), located in Paris, contains a curious Covenant of the Prophet. Titled "Nuskhat al-'ahd al-ladhī katabahu al-nabī li-ahl al-dhimmah," namely, "Copy of the Covenant that the Prophet Wrote to the Protected People," it is found in Majmü' fawā'id, namely, Compilation of Useful Information, a European-bound anthology compiled by Fāris al-Shidyāq (1804, 1805 or 1806-1887), a leading literary and intellectual figure in the Nahdah, namely, the Arab and Muslim Renaissance of the nineteenth century and one of the founders of modern Arabic literature.

Catalogued as MS. ARA. 44, Majmiu $\bar{u}^{\prime}$ fawa $\bar{a}^{\prime} i d$ is handwritten in Ottoman ta'līq script. It commences with five hundred and sixty-two notes on grammar, philology, syntax, and other related matters (f. 1-51). This is followed by the "Risālat al-imām al-Samarqandī fī al-istiārāt," a fifteenth-century treatise on rhetoric by Abū al-Qāsim ibn Abī Bakr al-Laythī al-Samarqandī (d. c. 1483-1484) that includes lexicological notes (f. $51 \mathrm{v}-128$ ). The copy of the "Covenant of the Prophet" is the third document in the work and appears on folios $128 \mathrm{v}-132$. It is basically the last work in the anthology. I have found this to be the case with other Covenants of the Prophet that I found in anthologies. Perhaps they were placed at the end for ease of location. Unlike other works that he copied under commission, the anthology in question contains works that were of personal interest to Fāris al-Shidyāq. His interest in linguistics is well known. Clearly, as a Christian living in the latter days of 
Ottoman rule, and as a person who had lived in Europe, he was interested in the "Covenant of the Prophet," perhaps as a means of securing protection for his faith community.

Although relatively late in comparison to other copies, many of which are centuries older, the "Covenant of the Prophet" copied by Fāris al-Shidyāq is curious on many counts. While its content is comparable to the six major charters of the Prophet that were studied in The Covenants of the Prophet Muhammad with the Christians of the World (Morrow 2013), the language employed in the "Covenant of the Prophet" copied by Fāris al-Shidyāq is not identical. Though the "Covenant of the Prophet" copied by Shidyāq contains certain clauses and conditions that I have not found in other covenants that I have scrutinized, it shares parallels with the "Covenant of the Prophet Muhammad with the Christians of the World" and the "Covenant of the Prophet Muhammad with the Christians of Najrān." The "Shidyāq Covenant" is significant as it bridges a gap with other covenants scribed

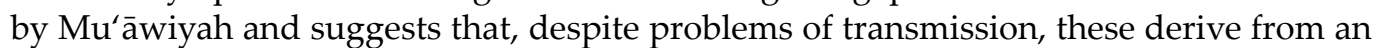
authentic historical document that he wrote down.

The work in which the covenant is found, Majmū fawā'id, belonged to Rashīd ibn Ghālib al-Dahdāh (1813-1889). On the first folio of the manuscript, there is a note signed by Dahụāh stating: "Assembled by Fāris al-Shidyāq. I acquired it via purchase from the one who had assembled it (i.e., al-Shidyāq) in London in 1857."1 Dahdāh, the owner of the manuscript, was born in 'Armun in 1813. He studied at the 'Ayn Warka school and the Bzummar Monastery and studied Islāmic law in Saida in 1843. He eventually moved to France, living in both Marseille and Paris. He founded a French/Arabic newspaper and authored many books. As for the "Covenant of the Prophet" found in Fāris al-Shidyāq's Majmū' fawā'id, it was copied from a manuscript found in the John Rylands Library in Manchester.

In the following pages, I provide a brief biography of the copyist, Fāris al-Shidyāq, drawn from Rebecca C. Johnson's foreword to Leg over Leg, G.J. Roper's entry in the Oxford Dictionary of National Biography, Mohammed B. Alwan's dissertation, and other biographical sketches, as it might shed some light on the history of the manuscript in question (Shidyāq 2015, pp. ix-xxxvi; Roper 2004; Roper 1998; Alwan 1970). I explore the provenance of the covenant and provide several leads for researchers. I reproduce the Arabic original as found in Majmiu' faw $\bar{a}^{\prime} i d$ along with an English translation which, Ibrahim Zein, Ahmed El-Wakil, and myself, have tried to align with the reconstructed Master Template (El-Wakil and Nasrallah 2017). This is followed by a critique of the covenant itself, along with a series of tentative conclusions, namely, that the "Shidyāq Covenant" from 1857 is a copy of the "Rylands Covenant," which appears to be an Ottoman-issued document dating from the sixteenth or seventeenth century. This "Shidyāq/Rylands Covenant" could represent the "missing link" between the "Covenant of the Prophet Muhammad with the Christians of Najrān," found in the Chronicle of Seert, and the "Covenant of the Prophet Muhammad with the Christians of the World," namely, the Testamentum et Pactiones made famous by Gabriel Sionita in (Sionita 1630).

The methodology employed in this study is historical-critical. It is concerned with the origins of the Covenants of the Prophet and their history of transmission. It also employs a hermeneutic approach. It builds upon the large body of scholarship in the field of Covenantal Studies, including Muhammad Hamīdullāh's Majmū'at al-Wathā'iq al-Siyāsiyyah li-l-'ahd al-nabawī wa-l-khīlafat al-rāshidah (Hamīdullāh 2001), 'Alī Ahmadī Miyānjī Makâtī̄b al-Rasūl (Miyānji 1998), the Covenants of the Prophet Muhammad with the Christians of the World (Morrow 2013), Isläm and the People of the Book: Critical Studies on the Covenants of the Prophet, a three-volume encyclopedic work (Morrow 2017), the works of Craig Considine (Considine 2021; Considine 2020; Considine 2016), as well as the scholarship produced by Ibrahim Zein and Ahmed El-Wakil (Zein and El-Wakil 2021; El-Wakil 2017, 2019a, 2019b; El-Wakil and Nasrallah 2017) and many others. If some topics appear to be too little analyzed or clarified, it is because they have been addressed in meticulous detail in previous scholarship on the subject. 
The "Shidyāq Covenant," which is studied in this article, is a variant of the "Covenant of the Prophet Muhammad with the Christians of Najrān" and the "Covenant of the Prophet Muhammad with the Christians of the World," two works that were the subject of in depth analysis in The Covenants of the Prophet Muhammad with the Christians of the World (Morrow 2013, pp. 109-76), not to mention the treatment they received in Islam and the People of the Book (Morrow 2017, vol. 2, pp. 95-131). Consequently, there is no need to repeat what has already been said. The purpose of this study is to move forward, not backwards, and to advance scholarship on the subject. The works listed above represent the bare minimum in terms of required reading on this topic. One study in particular, "The Provenance of the Prophet's Covenants," has tracked every available reference on the covenants found in Eastern and Western sources (Morrow 2017, vol. 2, pp. 1-213). It cites the opinions of virtually every author who has commented on the subject, analyzes their arguments, and responds to them. This current study relies on this scholarly foundation that spans over a millennium.

\section{The Copyist}

Fāris ibn Yūsuf al-Shidyāq was probably born in Ashqūt, in what is now Lebanon, but which, at the time, formed part of the Ottoman Empire, at the turn of the dawn of the nineteenth century. A Maronite Christian by birth, who belonged to an educated and distinguished family, Fāris al-Shidyāq rose to become a respected linguist, writer, journalist, and translator. His brother Assaad (1797-1830), who fell under the influence of Jonas King (1792-1869) from the American Board of Commissioners for Foreign Missions, converted to Protestantism, and was excommunicated by an edict issued by Youssef Hobaish (1823-1845), the Maronite Patriarch. As a result, Assaad was detained for years in the Monastery of Qannoubine where he died in 1830.

Fāris ibn Yūsuf al-Shidyāq was deeply marked by the death of his brother Assaad who had played a major influence in his life. Since his brother Tannous al-Shidyāq (c. 1794-1861) and cousin Bolous Massad (1806-1890) were complicit in the persecution of Assaad, Fāris never forgave them. After meeting with Isaac Beard, Fāris decided to convert to Protestantism. Fearing he would meet the same fate as his brother, Shidyāq set off for Egypt, where he lived between 1825 and 1848, and where he studied Islāmic jurisprudence at al-Azhar University. He also lived intermittently in Malta between 1833 and 1848 where "he was invited by American missionaries in Egypt to assist ... at the Arabic press" (Agius 1990, p. 52). As Dionisius A. Agius notes, "[h]e was also appointed as a lecturer in Arabic at the University of Malta from 1838-1848" (Agius 1990, p. 53). He was also brought to London "on special leaves of absence for various periods of time to carry out, in association with the British Arabists, Thomas Jarrett and Thomas Robinson, a new translation of the Bible into Arabic" (Agius 1990, p. 53).

In 1848, Fāris ibn Yūsuf al-Shidyāq was invited to settle in England by Samuel Lee (1783-1852), the orientalist, to participate in an Arabic translation of the Bible which was published in 1857. After living in the United Kingdom for seven years, Shidyāq became a British citizen. However, since he was unable to secure a teaching position, he relocated to Paris, France, for two years, where he published numerous serious works and made the not-so-serious claim that William Shakespeare's (1564-1616) original name was "Shaykh Zubayr" and that he was of Arabic origin. After Marie As-Souly, his first wife from a wealthy Syrian Christian family, and with whom he had two sons, passed away, Shidyāq married Safia, an English convert to Islām, with whom he had one child.

In the late 1850s, Shidyāq and his wife moved to Tunisia at the invitation of the Bey of Tunis where he was appointed editor in chief of a newspaper and supervisor of the Education Directorate. Formally a member of the Congregational Church, Fāris ibn Yūsuf al-Shidyāq embraced Islām in 1860 and adopted Ahmmad as his first name. Shortly after his conversion to the Muslim faith, he was invited by Sultan Abdel Majid I (1823-1861) to relocate to Istanbul where he was offered a position as an official translator for the Ottoman government and was known as Ahmmad Fāris al-Shidyāq Efendī. He also founded 
an Arabic newspaper, al-Jawā'ib in 1860/1861, which was supported by Turkish, Egyptian, and Tunisian rulers, and which ran until 1884. Despite Ottoman efforts to promote Turkish, Shidyāq remained a staunch defender of the Arabic language and culture which he viewed as foundational.

\section{The Provenance}

Since the manuscript compiled by Fāris ibn Yūsuf al-Shidyāq was purchased by Rashīd ibn Ghālib al-Dahdāh in 1857, it seems to predate Shidyāq's conversion to Islām, which reportedly possibly took place in Tunisia in 1860. One clue that it was before he adopted the Islāmic religion is the observation that the work "was collected by Fāris al-Shidyāq." ${ }^{2}$ His adopted Muslim name Ahmmad is not mentioned. The work could not, therefore, have been compiled during his time in Tunisia or Istanbul when he worked in an official capacity for the Ottomans. While it is remotely possible that he produced it while working and studying in Egypt, it seems more likely that it was either compiled in France in the mid-1850s where he was most prolific, or, even more so, during his seven year stay in the United Kingdom, where he worked with the British orientalist Samuel Lee (1783-1852).

Fāris al-Shidyāq does not give us any information as to where he found the manuscripts which he copied. In the first folio of the manuscript, he writes: "To proceed: What follows is useful information that I found during my readings and which I wanted to write down here. And success is with God." Was the "Covenant of the Prophet" obtained through Ottoman Muslim channels? Or was it obtained through the intermediary of European orientalists and libraries in the United Kingdom and France?

Since Shidyāq studied Islāmic jurisprudence at al-Azhar, could he have uncovered the "Covenant of the Prophet" through some of his Christian contacts in Egypt? Perhaps from the Copts or the Greek Orthodox? As Geoffrey Roper notes, Shidyāq "spent some time studying, and copying, Arabic literature with Muslim scholars in Cairo" (Roper 1998, p. 233). After all, Shidyāq was in Egypt between 1825 and 1848, a period of renewed interest in the Covenants of the Prophet. In 1882, Wilfred Scawen Blunt (1840-1922) provided a translation of a covenant of the Prophet in The Future of Islām (Blunt 1882, pp. 168-71) which "was being circulated last spring among the Ulema of the Azhar" (Blunt 1882, p. 168; Massé 1940, p. 196). The "Blunt Covenant" is a copy of a document that was written down

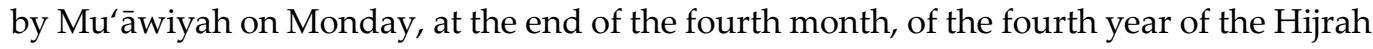
(Blunt 1882, p. 171). Is it therefore possible that Shidyāq found a variant of it in the archives of al-Azhar?

Although the Egyptian connection represents a distinct possibility, it is also possible that Shidyāq acquired the "Covenant of the Prophet" at some other point in what is now Lebanon or the Levant through Maronite Christian channels. After all, his cousin, Bolous Boutros Massad (Paul Peter Massad), served as the Maronite Patriarch from 1854 to 1890 and he may have come across copies of the Covenants of the Prophet. It should also be recalled that Fāris al-Shidyāq's brother, Tannous (c. 1794-1861), also happened to be a respected and well-published historian. Additionally, since Fāris al-Shidyāq played such a prominent role in the Nahdah, he interacted with a large body of literati who could have provided him with a copy of a covenant of the Prophet. In other words, even before he copied the "Covenant of the Prophet" from a manuscript that he had come across in the $\mathrm{Ma}$ $j m \bar{u}^{\prime}$ faw $\bar{a}^{\prime} i d$, Fāris al-Shidyāq may have been familiar with other copies of the "Covenant of the Prophet."

At the present, we only have leads, some stronger than the others, making the matter all the more intriguing. However, since the compilation also includes Samarqandī's "Risālah fī al-istiārāt," determining the place and time it was copied could help us pinpoint the provenance of the prophetic covenant. Unless he owned an ancient covenant of the Prophet, which seems unlikely, Shidyāq was likely working in a library copying documents that were difficult to obtain, of interest to him or of interest to a patron.

If we believe the life of Fāriyāq, the alter ego of Shidyāq, as conveyed in Leg over Leg, which is considered a foundational work of Arabic literature and even the first modern 
Arabic novel, Fāris al-Shidyāq was not fond of copying documents. Although he writes that copying manuscripts was his profession, he points out that it was "against his will" (94). In other words, it was merely something that he did for money. In fact, one of the characters in his novel describes the sight of Fāriyāq while working as a scribe:

I went, to find him o'er his copying bent, on his visage the first signs of transmogrification, eyes, as I beheld, deeply sunken, hand's suffering from desiccation, cheekbones as though from the face's surface hewn, skin as tight as the shade at noon, so that I deplored his state and came close to staying silent at his plight. (Shidyāq 2015, p. 115)

Since the binding was European, one could presume that the anthology was prepared in Europe. However, it is uncertain whether Shidyāq had the manuscript bound. It could also have been Dahdāh, who was based in France. It was also customary for European libraries to bound the manuscripts that they acquired.

Scholars and historians can be grateful that Shidyāq copied the covenant, that Dahdāh. bought it, that a French university purchased it for its library collection after 1857, and that the BULAC acquired it, digitized it, and placed it in the public domain. Since the BULAC was only founded in 2011, and its collection was drawn from more than twenty French universities, the provenance of the manuscript is uncertain. It is possible that it came from the Bibliotèque Nationale de France. In his Catalogue des manuscrits arabes (Paris 1883-1895) William McGuck, Baron de Slane (1801-1878), the Irish orientalist, spoke of the "Covenant of the Prophet with the Christians of the World," as "one of many redactions" (Morrow 2013, p. 144). The "Shidyāq Covenant" could be one of them. It is also possible that others await rediscovery.

\section{An Understudied Manuscript Tradition}

Since the publication of The Covenants of the Prophet Muhammad with the Christians of the World in 2013, more and more copies of the Covenants of the Prophet have come to surface. The notion that there are only a few isolated texts of the covenants in existence-having been discredited as forgeries by both Muslims and Christians but nevertheless recorded in obscure Christian chronicles by scribes who considered them of historical interest-is proving to be increasingly fallacious. Instead, the picture that emerges is that many copies were produced and disseminated. At times, these Covenants of the Prophet were copied on beautifully decorated manuscripts bearing the seal of a $q \bar{a} d \bar{\imath}$ or Islāmic judge to showcase that these were not ordinary documents, but rather represented official recognition and acceptance of Christianity by the ruling authorities, particularly by the Ottomans.

Na'ūm Shuqayr (1863-1922), Louis Cheikho (1859-1927), and Ahmmad Zakī Pāshā (1867-1934), regardless of their position on the authenticity of the covenants, are the most prominent Arab scholars to have documented the different copies of the covenants which they had come across. To this day, no complete database of all the Covenants of the Prophet which exist in various libraries, monasteries, and patriarchates, has been achieved, but such an endeavor is certainly needed as it would demonstrate that the issuance of copies of the covenants has a legal and religious precedent which was carried out throughout history by Muslim authorities.

Some of these copies have been recorded in my previous works, and it is increasingly obvious that in addition to the Greek Orthodox Church, the oriental churches were also given copies of the "Covenant of the Prophet." For instance, I recently rediscovered a copy of a covenant of the Prophet Muhammad directed to "all the dhimmīs of the Coptic community in the protected land of Egypt and its territories in which reside the Jacobite Christian dhimmīs." The work, titled "Nushat al-Ahdat allatī qālahā al-amīn Muhạmmad ibn 'Abd Allāh ibn 'Abd al-Muttalib," namely, "Copy of the Covenant which was Said by the Trustworthy Muhammad ibn 'Abd Allāh ibn 'Abd al-Mutțalib," is found on folios 267271 of MS Arabe 7216, Receuil d'ouvrages chrétiens. ${ }^{3}$

Although it only contains the first half of the "Covenant of the Prophet Muhammad with the Coptic Christians", which was reproduced and translated in Istām and the People 
of the Book (Morrow 2017, vol. 2, pp. 231-41), we find that numerous Oriental churches have copies of covenants which derived from this text. George Graf studied a copy of this covenant which was copied in the 1800s (Morrow 2017, vol. 2, p. 122). The copy found in MS Arabe 7216 is accompanied by a request that was submitted to the Egyptian treasury on 16 December 1886. Jeanne Aubert ${ }^{4}$ documented in 1938 a copy of the "Covenant of the Prophet" which "was found in the papers of a French officer who served ... during the Egyptian campaign (1798-1800)" (Morrow 2017, vol. 2, p. 122), and which too had been originally issued to Jacobite Christians. In addition to the Coptic Church, the Syriac Orthodox Church of Antioch and the Syriac Orthodox Archbishopric of Aleppo also have copies of the "Covenant of the Prophet" addressed to the Copts and Jacobites on beautifully decorated scrolls.

The Armenian Apostolic Church has various copies of covenants attributed to the Prophet, 'Umar and 'Alī. In 1870, Johannes Avdall brought to light a "Covenant of 'Alī" which had made its way into the archives of the Armenian Apostolic Church (Avdall 1870, pp. 60-64). Recently, Gayane Mkrtumyan has documented how many copies of the Prophet, 'Umar, and 'Alì's covenants exist in the Matenadaran, the Armenian Patriarchate of Jerusalem, and the Cathedral of New Julfa in Iran (Mkrtumyan 2021). As the manuscript tradition appears to confirm, the practice continued well into the nineteenth century and into the twentieth century, ending only with the collapse of the Ottoman empire.

What is important to note is that covenants, similar to the one copied by Shidyāq, were in circulation in official Christian and Muslim circles in the late 1800s. They also continued to be copied and quoted in the early twentieth century. In 1937, one year before the publication of Aubert's translation, Porphyrios III (r. 1926-1968), archbishop of St. Catherine's Monastery, invoked the "Covenant of the Prophet," urging the Egyptian government to respect the rights and privileges of the monks (Vincent 1939, p. 410). Clearly, there was a resurgence of interest in the Covenants of the Prophet during the 1800s, possibly provoked by the presence of French Catholics. Since the French authorities, including Napoleon (1769-1821) himself, were invoking the "Covenant of the Prophet," with the French leader going so far as to sign his name alongside the Companions of the Prophet, and issue his own edict, the Christians of Egypt may have felt empowered to reclaim their rights (Morrow 2017, vol. 2, pp. 19-26). The evidence, however, suggests a tradition of transmission that predates and post-dates the presence of European colonialists and seems to have formed a part of Christian-Muslim relations since the dawn of Islām. As for the covenant copied by Shidyāq, its text is as follows:

\section{The "Covenant of the Prophet" Transcribed by Shidyāq}

(Translated by Dr. John Andrew Morrow, Dr. Ibrahim Mohamed Zein, and Ahmed El-Wakil.)

$$
\text { نسخة العهد الذى كتبه النبى عم لاهل الذمة }
$$

This is a copy of the covenant [al-'ahd] that the Prophet, peace be upon him, wrote to the protected people [ahl al-dhimmah].

$$
\text { كتب عن نسخة كتبت عن الاصل و هو بخط معاوية بن ابي سفيان }
$$

It was written down from the original copy which was in the handwriting of $M u$ 'âwiyah ibn Ab̄̄ Sufyān.

وقد حرفه الناسخ تحريفا اخرجه عن ان يكون معزواً لاحد من العرب الاقدمين فضلا عن رسول الله افصح الخلق بالاجماع

The copyist [al-nāsikh] distorted its text [harrafahu] and so its language cannot therefore be attributed to the Arabs of old, particularly to the Messenger of Alläh who by consensus was the most eloquent of creation. [These are the words of Shidyāq and not the previous copyist of the document].

$$
\text { هذا الكتاب الاصلي كاتبه معاوية بن ابي سفيان باملاً الصصطفى صلى الله عليه وسلم و على آله اجمعين }
$$


This is the original document whose scribe is Mu'äwiyah ibn Ab̄̄ Sufyān as dictated to him by the Chosen One [al-Mustafä], may the blessings and peace of Alläh be upon him and all of his family.

$$
\text { بسم الله الرحمن الرحيم وبه العون }
$$

In the name of Allāh, the Most Compassionate, the Most Merciful and with His Help.

هذا الكتاب العزيز امر بكتبه5 خير خلق الله محمد رسول الله الى الناس كافة بشير ا ونذير ا على وديعة الله في خلقه لتكون

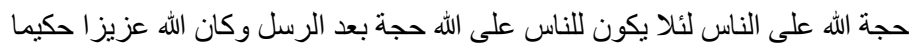

This precious document [al-kitäb al-'azizz] was written upon the command of the best of creation, Muhammad, the Messenger of Allāh, to all people, as a glad tiding and warning, as a trust Allāh has placed over His creation [wadi'at Allāh $f_{i}$ khalqihi] so that it serves as a proof of Allāh to the people, and for the people to have no excuse before Allāh after the messengers [rusul]. And Allāh is AllMighty and All-Wise.

كتب الى الحارث بن كعب عهدا وميثاقا من لدن رسول الله لاهل الملة المسيحية في مشرق الارض ومغربها وفصحها6

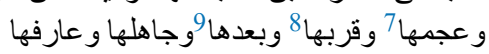

It was written to al-Hārith ibn Ka'b as a covenant ['ahd] and treaty [mīthāq] from the Messenger of Allāh to the followers of the Christian creed [ahl al-millat almasihiyyah] in the lands of the East and the West, Arabs and non-Arabs, those who are near and those who are distant, the ignorant ones [jähilihā] and the knowledgeable ones ['ärifihī].

$$
\text { يعلمون بان هذا الكتاب جعلته لهم عهدا وميثاقا مر عيّا وسجلّا منشور اووصية منى اقيم بها عدل الله وذمتي }
$$

They know that I granted this document [kitāb] to them as a covenant ['ahd], a binding treaty [mīthāqan mar'iyyan], a well-known certificate [sijjilan manshüran], and a testament [wasiyyah] from me, by which I apply [uqīmu] the justice of Allāh and my protection [dhimmatī] .

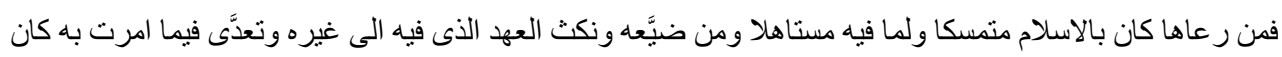

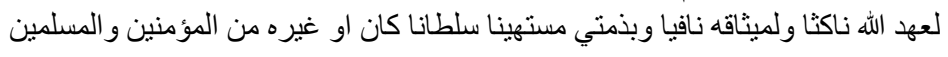

Whosoever abides by it is within the fold of Islām [mutamasikan] and is worthy of it. Whosoever breaks it and whosoever violates the covenant ['ahd] and what it contains by altering it, and violates what I have ordered therein, is a violator of the covenant of Allāh, a denier of His treaty, and a belittler of my protection [dhimmatī], whether he is a sovereign [șultān $]$ or any other among the believers [mü'minīn] and the Muslims [musliminn].

بان بذلت (بدأت) باعطاء العهود على (عن) نفسي و المو اثيق التي سالو ها منى و عن جميع اهل ملتي من المسلمين و احببت

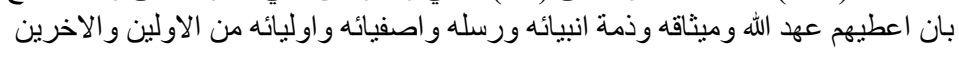

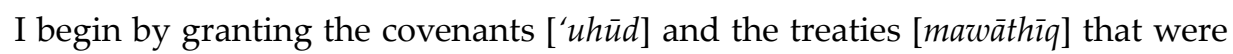
requested of me and from all those who belong to my community [ahl al-millatī] among the Muslims. I would like to grant them the covenant of Allāh and His treaty, and to place them under the protection of His prophets, His messengers, His chosen ones, and His saints, so that it be binding among the first and the last of them.

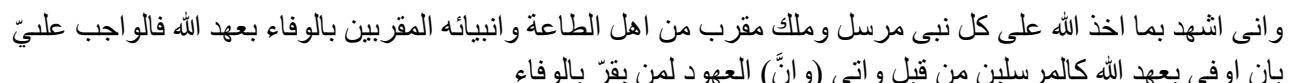

I bear witness by that which Allāh has taken from every prophet who was sent and every angel drawn near [to the divine throne] from the People of Obedience and the closest prophets [to God] that the covenant of Allāh ['ahd Allāh] must be fulfilled. Therefore, it is my obligation to fulfill the covenant of Allāh ['ahd Alläh] like the messengers before me and those covenants ['uhiud] which have been made and which are to be fulfilled. 
و هم النصارى اعطيتهم عهدي هذا وميثاقي الاحوى اقصاهم و ادنا بنفسي وخيلي ورجالي واعو أني اني و اتباعي من المؤمنين

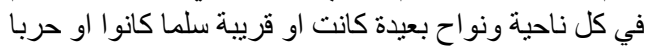

I granted the Christians this covenant ['ahdī] and treaty [mìthāqi $]$ of mine to protect them if they are far away and close to me with all my power, my cavalry, my men, my helpers, and my followers among the believers [mü'minin ] in every region, far or near, in times of peace and war.

اصنتهم 10 وعن ديار هم و عن بيعهم و ون صو امعهم ومواضع الر هبان منهم و عن كل سائح لهم حيث كانو ا واين كانو ا في جبل ام في واد ام في مفازة

I protect them, their homes, their churches [biy'ih im], their monasteries [sawamiai' $i$ him], the places [mawādi'] of their monks and the pilgrims belonging to them [i.e., to their religion], whenever and wherever they are, be they in a mountain, the valley, or the desert.

وكنفس الو اجب عليّ بان احوطهم و احوط دينهم وملكهم حيث كانو ا واين كانو ا في برّ ام بحر في شرق ام غرب احوطهم

Furthermore, it is my duty to protect their religion and their kingdom, whenever and wherever they are found, in land or at sea, in the east or in the west. I am protecting them by myself, by my [prophetic] seal [khātimin], and by the People of my Religious Community [ahl millatī] from among the believers [mü'minīn] and the Muslims [muslimīn].

و وان احلهم في امنى (امنى) و هم في امان الله واماني من كل اذى ومكروه و انادد (و اناضل)عنهم كل سلطنة وكل معاند

I place them under my security [amanī], and so they are under the protection of Allāh [amān Allāh] and under my protection [amānī] from all harm or adversity [makrūh]. I struggle against any oppressive power [saltanah] or opponent on their behalf.

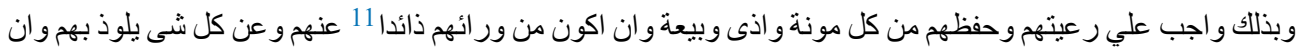

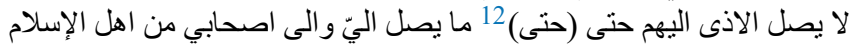

I must, therefore, care for them and protect them from all supplies, harm, and [forced] allegiance, and to stand behind them to defend and protect them, along with everything that belongs to them, to ensure that no harm reaches them unless it first reaches me and my companions from the People of Islām [ahl al-Islām].

وان اعزل عنهم الاذى من الموت13 وهو المعهد اليّ و لا يحمل من الخر اج الا ما طابت انفسهم به لا جبر ا14 و لا اكر اها

I shall keep the burden of supplies away from them, even for what they must give me. I shall not burden them with the land-tax [kharāj] except for what they voluntarily consent. They shall not be forced nor compelled in this matter.

$$
\text { وان لا يتغير اسقف عن اسقفيته و لا مطران عن مطرنيته و لا راهب عن منبته (رهبنته) و لا سائح عن بحته } 15
$$

What is more, no bishop shall be removed from his bishopric, no archbishop from his archbishopric, no monk from his monasticism [rahbanatihi], and no pilgrim from his pilgrimage.

$$
\text { و لا يكون احد من خلق الله يتعارض الى بيوت عبادتهم و لا ينهدم منها حجر واحد }
$$

Nobody in Allāh's creation has the right to interfere [yata'ārad] with their places of worship or to seize a single building block from them.

و لا يكون يدخل شى من الجدران التى لهم في بناء بيوت المسلمين و لا في المساجد فمن فعل غير هذا او خان عهدي هذا

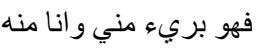

Nothing from within their walls shall be used to build the homes of Muslims or their mosques. Whosoever does such a thing or violates this covenant of mine ['ahdī], then I am free of him and he is free of me.

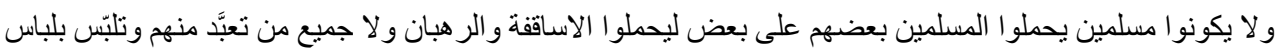

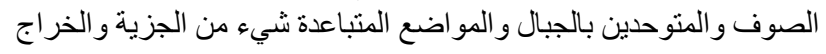


Muslims are not Muslims when they attack each other or when they attack bishops, monks, worshippers, those who wear woolen clothing, and hermits [mutawahidin $n$ residing in the mountains as well as in distant places, and they are not subject to the jizyah and the land-tax [kharāj].

$$
\text { على ان ليس على المتعبّد جزية البشر الا جزية الله التي هي الصوم و الصلوة و الدعاء للخلق و الطاعة لله }
$$

This is because those who have consecrated their lives to worship [muta'abbid] do not owe any jizyah to man, rather their jizyah is to Allāh in the form of fasting, prayer, supplications for fellow human beings, and obedience to Allāh.

$$
\text { و وامّا من كان من غير هم من النصارى فعليه الجزية الو اجبة وهى دينار حسب لا غير فمن تعدَّى واخذ غير هذا التقرير }
$$

Anyone among the Christians [nașārā] who is required to pay the compulsory jizyah shall only be required to pay one dīnār. Whosoever violates [this command], and takes more than what is prescribed, shall be cursed.

و اذا اخذت منهم الجزية المقررة كانت فى مال المسلمين لاجل الضعفا والمساكين ولا توخذ منهم قهر ا الا بطيبة من قلوبهم لا غصب

Whenever the prescribed jizyah is taken from them, it belongs to the treasury [māl] of the Muslims that is designated to provide for the weak and the poor. It is not to be taken from them by oppressing them, only by their own accord, and without force.

و ايضا لا تجوز الجزية على اصحاب المتجر و لا على استخر اج الذهب والفضة ولا الجوهر و غير هم من المعادن الا المونة التى تصل لبيت مال المسلمين علين اصنياب

No additional jizyah is to be collected from traders or those who extract gold, silver, gems, and other [precious metals and stones] (from mines) with the exception of the prescribed portion that is destined to reach the treasury of the Muslims [bayt māl al-muslimīn].

و لا يكون على عابر الطريق من الغربة شى من الجزية وانه ليس من اهل البلد وله الاحسان لاجل انه غريب و لا يكون

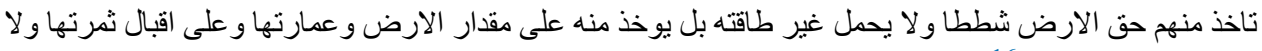

يجاوز عن حدّ الضجل الضرض 16

Foreign travelers have no right to the jizyah for they are not residents of the country. They are however to be treated kindly because they are in a foreign land. The right to the land is not to be taken from them and they should only give a just amount from the cultivation, development, and harvest of the land.

و لا يكلف احد من المسلمين لاهل الذمة الخروج الى عدو هم وملاقاة الحروب ومكاثشفة الاقران على انه ليس على اهل الذمة مباثرة القتال

It is not permissible for a Muslim to send anyone from the people under our protection [ahl al-dhimmah] to face their enemies, to engage in wars [hurūb] or to fight their counterparts [aqrān], as the people under our protection should not be exposed to the battlefield [mubāsharat al-qitāl].

و انما اعطى الذمة على ان لا يكلفوا بشى آخر و انما المسلمون اخذوا منهم الجزية لتكون مباثرة القتال لانفسهح و انهم

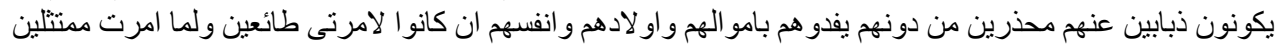

Since they have been granted our protection [dhimmah], they are discharged of all other obligations. And since the Muslims collect the jizyah from them, they must ensure that fighting on the battlefield be left up to them and that they defend them, warn them, sacrifice their money, their children, and themselves for them as long as they [i.e., the Muslims] follow and obey my commands.

و واما ملة النصارى فلا يكونوا يكر هون احدا من المسلمين اذا كانوا مباشرين قتال عدو هم بقوة من السلاح او من الخيل اذا

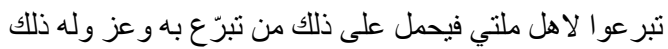


No one among the Muslims [muslimin], whenever they fight their enemies, should force the Christian community [millat al-nașārā] to provide weapons or horses. However, if they contribute to my religious community [ahl millatī], then this shall be acknowledged and appreciated.

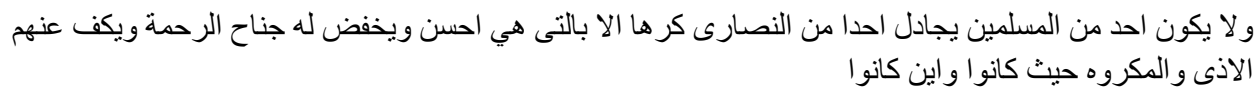

No one among the Muslims should dispute with anyone among the Christians [nașärā] except with means that are better (29:46). Rather, they should cover them with the wing of mercy and protect them from harm and adversity that could reach them whenever and wherever they are.

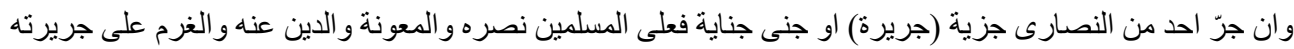

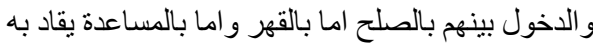

If any Christian were to commit a criminal offense [jarīrah] or a felony [janā jināyah], Muslims [musliminn] should stand by his side by helping and supporting him. They must safeguard him and pay the penalty of his offense. They should encourage reconciliation, either by intervention or by giving financial assistance as a form of retribution and compensation.

و لا يرفضو او لا يخذلوا و لاية او مهملا 17 فلهذا اعطيتهم عهد الله وذمتي على ان لهم ما للمسلمين و عليهم ما على المسلمين وللمسلمين ما لهم

They should not abandon them and leave them without help and assistance since I have granted them the covenant of Allāh and my protection ['ahd Alläh wa dhimmatī] to ensure that they and the Muslims have the same rights and obligations.

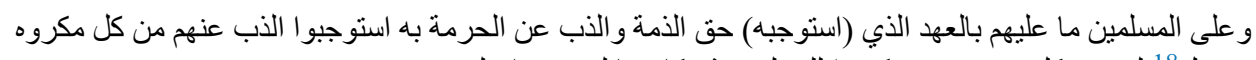

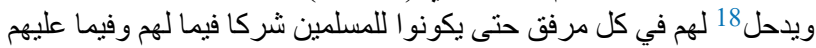

Furthermore, the Muslims have an obligation toward them with respect to the covenant, guaranteeing them the right of protection and safeguarding everything that is sacrosanct. They also have accepted that every mischief be removed from them and that they be bound to the Muslims so that they and the Muslims become partners with one another in the mutual rights and obligations that they share.

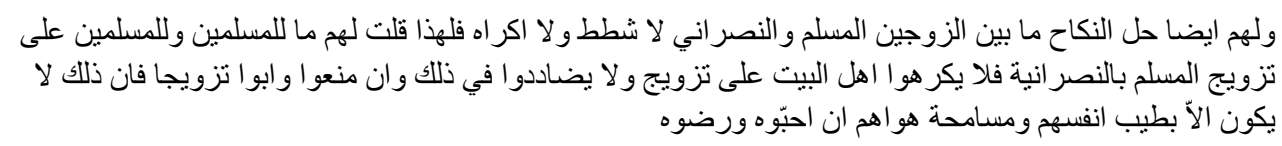

In addition, the marriage between Muslim and Christian spouses is permissible so long as it is without transgression and under no coercion. For that reason, I said to them that it is the right of a Muslim man to marry a Christian woman as he would a Muslim woman, and so the families of Christian women should not be coerced or harmed in this respect. Therefore, it is their right to refuse or reject a marriage proposal as these should be undertaken of their own accord, with their consent, and with their approval and authorization.

فاذا صارت النصر انية عند المسلمين فعليه رضى هو اها في دينها من الاقتداء بروسائها والاخذ بما يعامل دينها و لا يمنعها

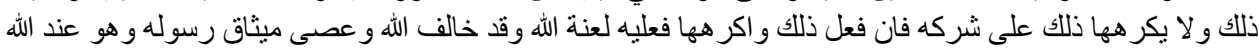
من الكذابين

If a Muslim takes a Christian woman as a wife, he must respect her Christian beliefs. He must support her religious aspirations so that she may receive religious instruction from her [clerical] superiors and he must allow her to fulfill her religious obligations. He must never prevent her from doing so. He must also not force her to act contrary to her religion or abuse her so that she abandons it. If he does this, and forces her, then he has broken the covenant of Allāh and violated 
the treaty [given to the Christians] by the Messenger of Allāh, and in the sight of Allāh he is among the liars.

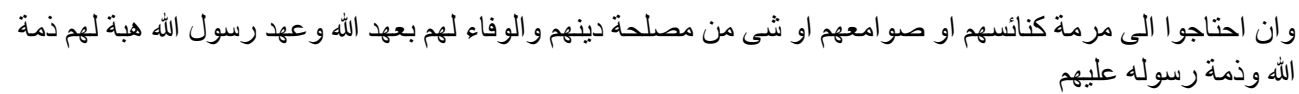

If they need to restore their churches or monasteries [sawāmi'ihim], or anything pertaining to their religion [ $d \bar{i} n]$, they must be assisted according to the covenant of Allāh and the covenant of His messenger. This must be given to them in the form of a gift as part of the protection [dhimmah] of Allāh and the protection [dhimmah] of His messenger which they enjoy.

و لا يكره احد منهم ان يكون بين المسلمين عدو هم 19 وقالو اله كن لنا رسو لا دليلا الى شى مما يقوم بنا فان (فمن) فعل ذلك ولك

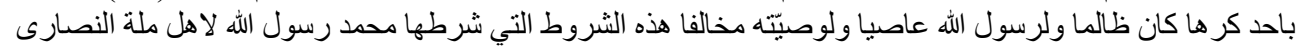

The Muslims should not force them to stand between them and their enemies and say to them: "Be one of our messengers, guiding [our army] through the terrain." Whosoever does this to any one of them is wrongful and disobedient to the Messenger of Allāh and to his testament. He has violated the stipulations which Muhammad, the Messenger of Allāh, decreed toward the religious community of Christians [ahl millat al-nașārā]].

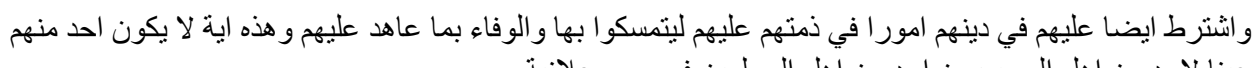
عينا لاحد من اهل الحرب من احد من أهل المسلمين في سر و وعلانية

He also stipulated in their religion [ $d \bar{i} n]$ responsibilities pertaining to their protection and which they must hold and abide to as part of the covenant. None of them should spy upon the Muslims, secretly or openly, on behalf of the People of War [ahl al-harb].

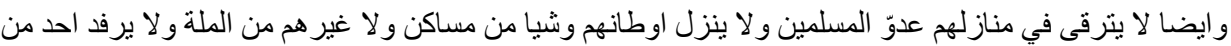

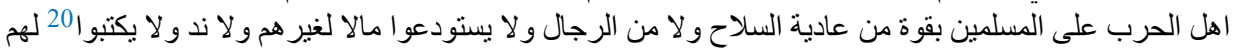

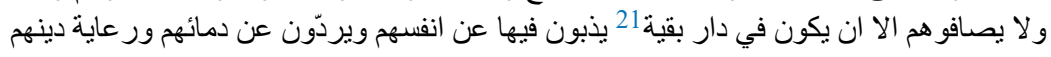

No enemies of the Muslims should ever stay in their houses or take up residence in their regions or habitations, even if they be their co-religionists. Moreover, they should not assist anyone from the People of War [ahl al-harb] against the Muslims by supplying them with weapons, fighters, or by retaining financial deposits. They are not to aid the enemies of the Muslims by writing to them or hosting them except that it should be out of fear for their lives, to prevent bloodshed, or to safeguard their religion $[d \bar{i} n]$.

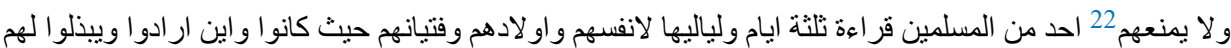

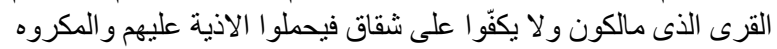

The Christians must not prevent the Muslims, along with those accompanying them and including their children, from staying with them for three days and three nights, wherever they are and wherever they wish. The Christians must offer them food and lodging from what belongs to them and they must not be overburdened in doing so. They must endure no harm or discomfort for their hospitality.

و ان احتاج احد من المسلمين الى اخفاء في مناز لهم ومو اطن عبادتهم فلا يردو هم و لا ير فضو هم وير اسو هم 23 عما ثبوته لهم لهم

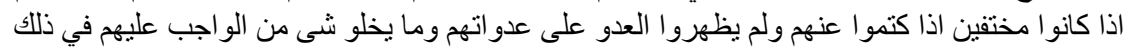

If one of the Muslims needs to hide in one of their homes or in one of their places of worship, they must grant him hospitality, help him, and stand by his side so long as the Muslim remains in hiding. They must conceal him from the enemy, not disclose his location and accommodate for all of his needs.

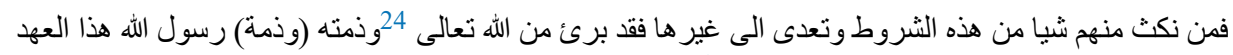

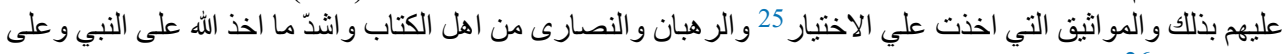

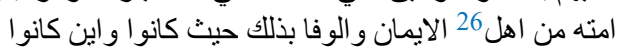


Whosoever contravenes any of these conditions or transgresses them by altering them has freed himself of the protection of Allāh and that of the messenger of Allāh. This covenant [al-'ahd] is for them as well as the treaties [mawāthīq] that I chose to take from the Christian scholars, the monks [al-ruhbān], and the Christians [nașāra $\bar{a}$ from the People of the Book [ahl al-kitäb]. It is the most stringent oath that Allāh has taken from a prophet and his community [ummah].

$$
\text { و وتقضى رسنيال الله بما جعله على نفسه و على المسلمين رعاية ذلك لهم ومقرتهم } 27 \text { به و الانتهاء اليه ابدا حتى تقوم الساعة }
$$

The Messenger of Allāh has decreed that it is binding on himself and all of the Muslims who should know and observe its stipulations. It is an everlasting [covenant], valid until the Day of Judgment and the End of Time.

$$
\text { و انشهد على هذا الكتاب الذي امر بكتبته } 28 \text { محد رسول الله لاهل ملة النصر انية واشرط عليهم وكتب لهم العهد }
$$

Those who bore witness to this document [kitāb] which Muhammad, the Messenger of Allāh, ordered to be written to the followers of Christianity [ahl millat al-nasräniyyah]. He wrote for them the stipulations found in the covenant and granted it to them.

$$
\text { و هو لا الثهود اصحاب رسول الله صلى الله عليه و على آله اجمعين }
$$

These are the witnesses who are the companions of the Messenger of Allāh, may

\begin{tabular}{|c|c|c|}
\hline 1 & Abū Bakr al-Șiddīq; & ابو بكر الصديق \\
\hline 2 & ‘Umar ibn al-Khatṭāb; & عمر بن الخطاب \\
\hline 3 & ‘Uthmān ibn ‘Affān; & عثمان بن عفان \\
\hline 4 & 'Alī ibn Abī Ṭālib; & علي بن ابي طالب \\
\hline 5 & Mu'āwiyah ibn Abī Sufyān; & معاوية بن ابي سفيان \\
\hline 6 & Abū al-Dardā; & ابو الدَردْاء \\
\hline 7 & Abū Hurayrah; & ابو هريرة \\
\hline 8 & Abū Dharr; & ابو ذر \\
\hline 9 & 'Abd Allāh ibn 'Abbās; & عبد الله ابن عباس \\
\hline 10 & 'Abd Allāh ibn Mas'.ūd; & عبد الله بن مسعود \\
\hline 11 & Hamzah ibn 'Abd al-Muttalib; & حمزة بن عبد المطلب \\
\hline 12 & al-Fadl ibn 'Abbās; & الفضل ابن عباس \\
\hline 13 & al-Zubayr ibn al-'Awwām; & الزبير بن العوام \\
\hline 14 & Ṭalhah ibn ‘Abd Allāh; & طلحة بن عبد الله \\
\hline 15 & Sa'd ibn Mu'ādh; & سعد بن معاذ \\
\hline 16 & Sa'd ibn 'Ubād; & سعد بن عباد \\
\hline 17 & Thābit ibn Qays; & ثابت بن قيس \\
\hline 18 & Zayd ibn Thābit; & زيد بن ثابت \\
\hline
\end{tabular}
the peace and blessings of Allāh be upon him and all of his family.

اول الثهود

The first witnesses are: 


\begin{tabular}{|c|c|c|}
\hline 19 & 'Abd Allāh ibn Zayd; & عبد الله بن زيد \\
\hline 20 & Harqūsh ibn Zayd; & حرقوش بن زيد \\
\hline 21 & Zayd ibn Arqam; & زيد بن ارقم \\
\hline 22 & Usāmah ibn Zayd; & 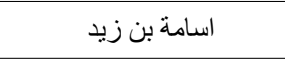 \\
\hline 23 & Sahl ibn Binhān; & سهل بن بنهان \\
\hline 24 & ‘Uthmān ibn Mat’ūn; & 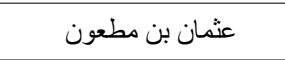 \\
\hline 25 & Dhuwāb ibn Ḥayr; & 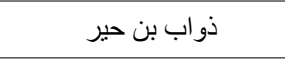 \\
\hline 26 & Abū al-Hāliyah; & 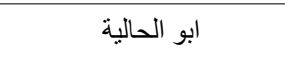 \\
\hline 27 & 'Abd Allāh ibn 'Umar al-Qādị;' & عبد الله بن عمر القاضي \\
\hline 28 & Abū Hudhayfah ibn ‘Umar ibn Rabī’ah; & ابو حذيفة بن عمر بن ربيعه \\
\hline 29 & 'Ammār ibn Yāsir; & عمّار بن باسر \\
\hline 30 & Hishām ibn Ghusạa; & هانم بن غصه \\
\hline 31 & Hassān ibn Thābit; & 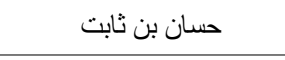 \\
\hline 32 & Ka'b ibn Mālik; & كعب بن ماللك \\
\hline 33 & Ja'far ibn Abī Ṭālib; & جعفر بن ابي طالب \\
\hline 34 & Khālid ibn al-Walīd; and & 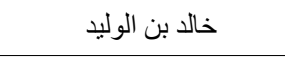 \\
\hline 35 & Bilāl al-Habashī & بلال الحبشي \\
\hline
\end{tabular}

$$
\text { هذه اصحاب النبي الشهود عليه بهذه الشروط }
$$

These are the companions of the Prophet who witnessed these terms [shurūt].

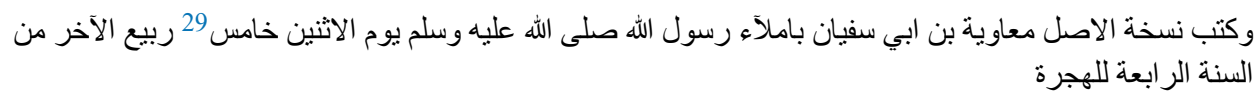

The original copy was written down by Mu'āwiyah ibn Abī Sufyān as dictated by the Messenger of Allāh, may the peace and blessings of Allāh be upon him, on Monday, on the fifth of Rabi' $\overline{1}^{\star}$ al-ÂAhir, in the fourth year of the Hijrah.

$$
\text { بالمدينة حرسها الله وكفى بالله شهيدا على ما في هذا الكتاب }
$$

[Written] in Madīnah which is protected by Allāh. And Allāh is sufficient as a witness [wa kafā bi-Lähi shahīdan] to what is contained in this document.

\section{The Critique}

Since the Covenants of the Prophet have been subjected to detailed textual analysis in the Covenants of the Prophet Muhammad with the Christians of the World, along with other works, this critique will limit itself to distinguishing features and differences so as to not repeat what has already been said (Morrow 2013, 2017). For the sake of clarity, I will refer to this covenant as the "Shidyāq Covenant."

\subsection{Structure, Style, and Substance}

The structure of the "Shidyāq Covenant" is the same as the other major covenants. The language is highly similar. Most of the variants are minor and are typically due to different possible readings of the Arabic consonantal skeleton. As Gayane Mkrtumyan explains, "[t]his consistency implies that they have roots in some original Arabic text that was copied and disseminated to different Christian communities living under Muslim rule" (Mkrtumyan 2021, n. page). Additionally, when it comes to content, the "Shidyāq Covenant" is essentially the same. There is no blatant evidence of tampering by deletion. Further, there is no blatant evidence of tampering by addition. The variations between the "Shidyāq Covenant" and other manuscripts fall within a reasonable range. 


\subsection{Bishops and Beyond}

The differences between the "Shidyāq Covenant" and other surviving manuscripts are minor. For example, the "Shidyāq Covenant" decrees that "no bishop [usquf] will be removed from his bishopric, no archbishop [matrān] from his archbishopric, no monk [rāhib] from his monasticism, and no pilgrim from his pilgrimage [s, $\left.\bar{a}^{\prime} i h\right] . "$ Though other covenants mention bishops, monks, and pilgrims, with no mention of archbishops, we nevertheless find that the "Shidyāq Covenant" is interconnected to the covenants and compacts of the Prophet.

When we examine the Prophet's "Compact with the People of Najrān" in the Islāmic sources, we find that the recension in the Tafsìr of Muqātil ibn Sulaymān al-Balkhī (d. 767 CE) refers to the bishop [usquf] and the monk [rähib] (Balkhī 2002, p. 325). The text cited by Abū Yūsuf (d. 798) and Ibn Kathīr (d. 1373) mentions the bishop, the monk, and the priest [kāhin] (Abū Yūsuf 1979, p. 72; Ibn Kathīr 1988, p. 55). The version of Ibn Sa'd (d. 845 CE) mentions the bishop, the monk, and the stylite [wāqif] (Ibn Sa'd 1990, p. 220). Muhammad ibn al-Hasan al-Shaybānī (d. 805 CE), Abū 'Ubayd al-Qāsim ibn Sallām (d. 838 CE), Ibn Shabbah (d. 877), and al-Balādhurī (d. 892 CE), speak of the bishop and the monk but also include the deacon or church administrator [wäqih] (Shaybānī 1975, p. 267; Abū 'Ubayd 1989, p. 281; Ibn Shabbah 1979, p. 585; Balādhurī 1987, pp. 87-88). "Abū Bakr's Compact with the People of Najrān" states that "no bishop or monk shall be removed from his position" (Abū Yūsuf 1979, p. 73; Țabarī 1969, vol. 2, p. 535).

As for the covenants originating from Christian sources, we find that the "Covenant of Najrān" from the Chronicle of Seert talks about the bishop, monk, and pilgrim (Morrow 2017, vol. 1, pp. 28-29). The short recension of the "Sinai Covenant" includes the bishop, the priest, the hermit who sits in his tower [habis], and the pilgrim (Morrow 2017, vol. 1, p. 29). The "Covenant with the Christians of the World" from 1538 mentions the bishop, monk, and Christian [nașrānī], along with the pilgrim (Morrow 2017, vol. 1, p. 29). The "Covenant with the Christians of the World" from 1630 speaks of the bishop, the Christian, the monk, and the pilgrim, as well as the hermit (Morrow 2017, vol. 1, p. 29). The Persian and Assyrian Covenants only mention priests (Morrow 2017, vol. 1, pp. 29-30).

\subsection{Muslims Are Not Muslims...}

Another difference found in the "Shidyāq Covenant" is the sentence that states that "Muslims are not Muslims when they attack each other or when they attack bishops, monks, worshippers, those who wear woolen clothing, and hermits [mutawahidin] residing in the mountains as well as in distant places, and they are not subject to the jizyah and the land-tax [kharāj]." This could be an interpolation. If it were included in the original, it could have been removed by a Muslim scribe since it was at the center of a theological debate. Some theologians argued that a Muslim who committed a major sin abandoned Islām. Others argued that sin, however severe, was not tantamount to apostasy. Yet others claimed that Muslims who committed major sins were only non-Muslims during the act; however, they returned to Islām after it was accomplished. However, the additional sentence in question finds parallels in the other Covenants of the Prophet which warn that anyone who breaks them becomes an enemy of the Prophet, Islām, and God, and is destined for damnation. So, one cannot say that the sentence in question is a fabrication. Additionally, even if it were a type of textual commentary or expansion, it was not one that was created ex nihilo.

\subsection{To Tax or Not to Tax}

Yet another interesting difference deals with taxation. The "Shidyāq Covenant" states that "those who have consecrated their lives to worship [muta'abbid] do not owe any jizyah to man, rather their jizyah is to Allāh in the form of fasting, prayer, supplications for fellow human beings, and obedience to Allāh." It provides a spiritual take on taxation. It explains that the taxes of the devout consist of fasting, praying, supplications, and obedience to God. This supports the position of the Covenants of the Prophet that prohibit the taxation of clerics and religious orders. 
One striking difference deals with currency. It states that Christians are required to pay one dīnār as jizyah. Although MS 274 from the Archives of the Divan of the Catholicos of All Armenians in the Matenadaran stipulates four dīnārs and twelve dirhāms, Mkrtumyan argues that "this is most certainly a mistake in translation as it differs from MS 358 and other Arabic copies of the covenants, which stipulate a rate of 4 dirhāms for the ordinary folk and 12 dirhāms for the rich" (Mkrtumyan 2021, n. page).

The "Sinai Covenant" speaks of twelve dirhāms per year for wealthy Christians (Morrow 2013, p. 216) as does the "Persian Covenant" (Morrow 2013, p. 224), the two versions of the "Covenant with the Christians of the World" (Morrow 2013, pp. 234, 239), the "Najrān Covenant" (Morrow 2013, p. 298), the "Syriac Covenant" (Morrow 2017, vol. 2, p. 343), and the "Armenian Covenant" (Morrow 2017, vol. 2, p. 477). The "Assyrian Covenant," however, distinguishes between one dīnār for working Christians and twelve dīnārs for wealthy Christians (Morrow 2013, p. 313). The “Coptic Covenant" charges merchants seven dirhāms (Morrow 2017, vol. 2, p. 238).

The covenants with the Jews provide different taxation rates. The "Treaty of Maqnā" found in Muslim sources speaks of "a quarter of your date harvest, a quarter of your fishing yield, and a quarter of the yarn spun by your women" (Morrow 2013, p. 54; Morrow 2017, vol. 2, p. 285). One covenant with the Jews calls for them to "pay the jizyah: three silver mithqäls" (Morrow 2017, vol. 2, p. 291). Another calls for "one fifth of the mines of the land ... and its resources," five qaflahs annually for merchants, and one and a half for the poor (Morrow 2017, vol. 2, p. 295). As for the "Covenant of 'Alī with the Parsis," the requirement was "one dirhām per year as tribute" (Morrow 2017, vol. 1, p. 532).

While there was variation, the Islāmic dirhām was approximately 2.275 grams of silver whereas a dīnār was normally $4.250 \mathrm{~g}$ of gold (Zarra-Nezhad 2014, pp. 56, 53). Both coins have roughly the same diameter. In "A Brief History of Money in Islām and Estimating the Value of Dirhām and Dīnār," Mansour Zarra-Nezhah found that a dīnār was worth the equivalent of $\$ 32.50$ to $\$ 36.50$ USD during the first century of the Hijrah according to the value of the dollar in 2004. The exchange rate of dinār to dirhām was "determined by the demand for and supply of gold and silver" (Zarra-Nezhad 2014, p. 63). During the caliphate of 'Umar, each dīnār was equal to 13 dirhāms (Zarra-Nezhad 2014, p. 63). During the rule of Hishām ibn 'Abd al-Malik, "[t]he rate rose to 15 dirhāms to each dīnār" (ZarraNezhad 2014, p. 63). By two hundred and fifty years after the Hijrah, it rose to 22 dirhāms (Zarra-Nezhad 2014, p. 63). Fifty years later, it was valued at 10 dirhāms and by "the middle of the Fātimid rule, the value of dīnār again rose and reached 18 dirhāms" (Zarra-Nezhad 2014, p. 63).

The "Shidyāq Covenant" reads: "Anyone among the Christians [nasạāā] who is required to pay the compulsory jizyah shall only be required to pay one dìnār." What is missing, and appears to be an accident, is the distinction between ordinary Christians and wealthy merchants. If one dīnār was roughly twelve dirhāms during the seventh century, then the call for them to pay one dīnār per year as jizyah made in the "Shidyāq Covenant" is not the product of tampering: one dīnār was synonymous with twelve dirhāms. According to the "Covenant with the Christians of the World" from 1630, regular Christians were only to pay four dirhāms as jizyah (Morrow 2013, p. 238), as also stipulated by the "Najrān Covenant" (Morrow 2013, p. 298), the "Persian Covenant" (Morrow 2013, vol. 2, p. 224; Morrow 2017, vol. 2, p. 531), and the "Covenant with the Armenian Christians" (Morrow 2017, vol. 2, p. 477) all of which are scribed by Mu'āwiyah. A rate of four dirhāms for those who are ordinary people is also found in the "Samaritan Covenant" and the "Covenant with the Christians of the World" from 1538 (Morrow 2013, p. 238).

Critics of the covenants often claim that they were concocted by Christians in an attempt to lower their tax rate. If so, why would any forger actually increase the tax rate of his community by raising it from four dirhāms to one dinnār, which is the equivalent of a dozen or more dirhāms? Additionally, while some scholars might use these difference tax rates to claim that the covenants are forgeries, Rachel Hutchings has shown that "the form in which jizyah was paid by non-Muslims was flexible ... during the conquests" 
(Hutchings 2020, p. 22). Consequently, this diversity can be used to uphold claims of authenticity. Critics, however, would argue that the jizyah and kharäj only became separated in post-prophetic times and that the distinction between both represent an insurmountable anachronism. Supporters, however, would counter that the kharäj does indeed trace back to the time of the Prophet Muhammad and was known then as jizyat al-kharāj.

\subsection{The Copyist}

The manuscript copied by Fāris al-Shidyāq commences with the words: "This is a copy of the covenant [al-'ahd] that the Prophet, peace be upon him, wrote to the protected people [ahl al-dhimmah]." This is the standard formula found on virtually every other covenant of the Prophet with only slight variations. The covenant claims that

It was written down from the original copy which was in the handwriting of Mu'āwiyah ibn Abī Sufyān.

The copyist [al-nāsikh] distorted its text [harrafahu] and so its language cannot therefore be attributed to the Arabs of old, particularly to the Messenger of Allāh who by consensus was the most eloquent of creation.

This is the original document whose scribe is Mu'āwiyah ibn Abī Sufyān as dictated to him by the Chosen One [al-Mustafä], may the blessings and peace of Allāh be upon him and all of his family.

Consequently, the document belongs to the body of covenants that were reportedly copied down by Mu'âwiyah during the fourth year of the Hijrah. While Islāmic sources, written several centuries after the fact, under 'Abbāsid rule, the inveterate enemies of the Umayyads, paint an unfavorable portrait of Mu'a âwiyah, the earliest Christian sources, dating from decades after his rule, imply that he adhered to the "Covenant of the Prophet" while he was governing. In his Universal History, written in $687 \mathrm{CE}$, a mere sixty-seven years after the Hijrah, John Bar Penkaye wrote:

A man among them named $\mathrm{Mu}^{\prime}$ âwiyah took the reins of government of the two empires: Persian and Roman. Justice flourished under his reign, and a great peace was established in the countries that were under his government and allowed everyone to live as they wished. They [i.e., the Muslims] had received, as I said, from the man who was their guide [i.e., Prophet Muhammad], an order [i.e., a covenant] in favor of the Christians and the monks ... Of each person, they required only tribute [i.e., the jizyah] allowing him to remain in whatever faith he wished ... While $\mathrm{Mu}^{\prime}$ àwiyah reigned there was such a great peace in the world as was never heard of, according to our fathers and our fathers' fathers ... There was no difference between pagan and Christian, the believer was not distinct from the Jew, and did not differ from the deceiver. (El-Wakil 2019b, n. page; Mingana 1908a, p. 175)

Although Mu'āwiyah's name was blackened by both the 'Abbāsids, the Khārijites, the Shī'ites, and those that followed them, parties that generally denied that he was an early companion who acted as the Prophet's amanuensis,

The Islāmic sources could not completely do away with the collective memory of Mu'âwiyah having been a scribe of the Prophet, though they did attempt to minimize his influence. There appear to be only four pieces of correspondence of the Prophet in the Islāmic sources that list Mu'āwiyah as their scribe: (1) to the Banū Qurra ... , (2) to Rabīa b. Dhī al-Mirhạa ... , (3) to Bilāl b. al-Hārith ... , and (4) to the people of Jurash ... - all of which are unfortunately not dated. Though the letter to al-Alā b. al-Hadramī may have attempted to obscure the scribe's name by referring to him as 'Ibn Abī Sufyān', it is quite obvious that this could have been no one other than $\mathrm{Mu}^{\prime}$ āwiyah. Thus, the letter to al-'Alā' is the only document in the Islāmic sources confirming Mu'āwiyah's relatively early conversion to Islām and that he was a trusted scribe of the Prophet. (El-Wakil 2019a, p. 8) 


\subsection{The Date}

The covenant in question appears to indicate that it was written on yawm al-ithnayn khāmis rabi' al-äkhir min al-sanah al-rābi'ah al-hijriyyah or "Monday, on the fifth of Rabi' al$\bar{A}$ khir, in the fourth year of the Hijrah." However, this poses a problem. In the fourth year of the Hijrah, the fifth of Rabī' al-Ākhir fell on either a Friday or a Saturday; not a Monday (https://keisan.casio.com/exec/system/1346122065 accessed on 4 April 2021). While one could argue that the mismatched day and date suggests that the document is a forgery, this could be the result of a misreading or misprint of the original which might have stated that it was written on yawm al-ithnayn fì khitām arba'at ashhur min al-sanah al-rābi'ah min al-hijrah, that is, on "Monday at the closing of the fourth month of the fourth year of the Hijrah," which appears in the "Cheikho Covenant," or perhaps on yawm al-ithnayn li-tamām arba'at ashhur min al-sanah al-räbi'ah al-hijriyyah, namely, on "Monday, at the end of the fourth month of the fourth year of the Hijrah." As Ibrahim Zein and Ahmed El-Wakil have demonstrated:

The "Prophet's Covenant with the Christians of the World," which was written by $\mathrm{Mu}^{\prime}$ āwiyah on Monday $29 \mathrm{Rabī}^{\prime}$ al-Ākhir $4 \mathrm{AH}$, has been extensively documented through a series of manuscripts. It is one of those rare covenants which has the specific date of the week appended to it and when we apply Specific Date Verification, we find that it accurately returns as Monday 7 October AD 625 on the SAC [Standard Astronomical Calendar]. This is a strong piece of evidence for its authenticity as it is highly unlikely that Christians unfamiliar with the Hijrì calendar would have forged a document of this nature by being correct to the day of the week. (Zein and El-Wakil 2021, n. page)

Zein and El-Wakil have listed eight transmissions of covenants with this accurate date, including, but certainly not limited to: (1) manuscript 358, the seventeenth-century copy of the covenant from the Matenadran in Armenia which has been studied by Mkrtumyan; (2) the copy from the Monastery of St. George al-Humayrā', which I brought to light in the second volume of Islām and the People of the Book; (3) manuscript 1123, the covenant from the Hill Museum and Manuscript Library, which seems to date from the nineteenth century; (4) Dossier 27 No. 27 from St. John's Monastery in Patmos; (5) Gabriel Sionita's Testamentum et Pactiones Initae inter Mohamedem et Chritianae Fidei Cultores, which was published in 1630; (6) the covenant published by Louis Cheikho in 1910; (7) the Persian recension published by George David Malech in 1910; (8) and, finally, the English translation of a Persian covenant that was reproduced by Leon Arpee in 1946.

To this list, we can include the "Covenant of the Prophet" translated by William Scawen Blunt in 1882 which includes the same date: Monday, at the end of the fourth month, of the fourth year of the Hijrah (Blunt 1882, p. 171). As Zein and El-Wakil note,

All of the recensions of the "Covenant with the Christians of the World" agree on the date despite the slight variations in wording. The Sionita and the St. George al-Humayra' recensions read "yawm al-athnayn tamām arbaat ashhur min al-sanah al-räbiah min al-hijrah bi-l-Madinah;" GAMS 1123 reads "yawm al-athnayn li-tamām arbaat ashhur min al-sanah al-räbiah min hijrah al-Madīnah;" the copy in the Greek Orthodox Patriarchate of Jerusalem and that documented by Father Gabriel Akyüz reads "yawm al-athnayn li-tamām arbatat ashhur min al-sanah al-räbiah min hijrah al-Madīnah;" Cheikho's "yawm al-athnayn fì khitām arba'at ashhur min alsanah al-rābi'ah min al-hijrah bi-l-Madinnah;" and MS 358 in the Matanedaran "yawm al-athnayn al-tamām arba'at ashhur min al-sanah al-rābi'ah min al-hijrah bi-l-Madinah." The Persian manuscript reproduced by Malech reads "rūz'i dūshanbah ākhir-I māhi chahārum az sāl-i chahārum az Hijraht bi-Madīnah," while Arpee's translation of the Persian manuscript in New Julfa, Iran, reads "this Treaty was drawn up on the Monday following the first four months of the Fourth Year of the Hegira." (Zein and El-Wakil 2021, n. page) 
As is the case with most of the major Covenants of the Prophet, Shidyāq's copy claims that it was "[written] in Madīnah which is protected by Allāh. And Allāh is sufficient as a witness [wa kafā bi-l-Lāhi shahīdan] to what is contained in this document." This phraseology is the same as appears in the Covenants of the Prophet and 'Ali (Mkrtumyan 2021, n. page). It also echoes its variant, wa kafä bihi shahīdan, namely "and sufficient is He as a witness" that appears in "The Capitulation Treaty of Habīb ibn Maslamah issued during the caliphate of "Uthmān" (Mkrtumyan 2021, n. page), suggesting it belongs to the terminology of early Islāmic political documents.

If we rely solely upon its date, Monday $29 \mathrm{Rab}^{\prime}{ }^{\prime}$ al-Ākhir $4 \mathrm{AH}$, and its scribe, Mu'āwiyah ibn Abī Sufyān, we might be inclined to treat the Shidyāq manuscript as another rendition of the "Covenant of the Prophet Muhammad with the Christians of the World." However, it features short segments that are identical to the "Covenant with the Christians of Najrān" from the Chronicle of Seert. This potentially means that it has retained unique features from the original "Covenant with the Christians of Najrān" which subsequently bifurcated into two versions: the first being the version found in the Chronicle of Seert and the second being the version which exists as various recensions of the "Covenant with the Christians of the World." It may therefore be a missing link between both versions, representing a manuscript tradition prior to bifurcation.

\subsection{The Witnesses}

The witnesses that appear on copies of the Covenants of the Prophet have been the subject of much debate. It has been proposed that they are genuine. It has also been suggested that the names were added to the documents to provide them a greater air of authenticity. Both sides of the issue were studied in "Examining the Authorities" (Morrow 2013, pp. 323-30). The most recent scholarship on the subject, which consists of a crosscomparison of half a dozen documents, and which addresses the concerns of critics, suggests that the names of the witnesses are both consistent and in perfect harmony with the Covenants of the Prophet (El-Wakil and Nasrallah 2017). This current study seems to support those findings.

With the exception of Khālid ibn al-Walīd and Bilāl al-Habashī, the thirty-five witnesses mentioned in the "Shidyāq Covenant" are the same as found on most of the other Covenants of the Prophet. Some of the names, however, are deformed. Their original forms, however, are identifiable. The "Shidyāq Covenant" does not feature any of the more bizarre names found in the "Covenant of the Prophet Muhammad with the Coptic Christians" or Jeanne Aubert's Serment du Prophète such as Abī al-Ward, 'Abd Allāh ibn 'Abd al-Wāhịd, Ibn Șafiyyah, Abā Qādir, and Ramadạ̄n ibn 'Abd Allāh al-Ṭālib in the former (Morrow 2017, vol. 2, p. 241), and Marsūs ibn Qāsim, 'Abd Allāh ibn Maryam, 'Abd al-'Az̄̄m ibn Hasan, Mīr ibn Ibrahīm, Umāmah ibn Marīr, 'Uthmān ibn 'Abd, Mu'zam ibn Mūsā, Abū Hayfah, and Abū al-Nādir in the latter (Aubert 1938, p. 39).

It appears that these unusual names are the result of attempts to reconstruct names that were nearly undecipherable. Still, one would have expected the copyist to align the text with actual names in the Arabic language. Marsūs, for example, is a Latin name. Do the more unusual names belong to members of a Christian delegation? In a treaty between two parties, one would expect witnesses from both of them. Some of these names are so strange to the ear that one could scarcely believe that a serious forger would try to pass them off as belonging to the Arab Muslim companions of the Prophet from Madinah. These names do not make or break the covenant. They represent an intriguing anomaly that needs further research to be satisfactorily resolved.

It is interesting to note that the list of witnesses at the end of the document is virtually identical to MS 358 which is in the Matenadaran. The following names are the same in both manuscripts but were deciphered as follows by the copyist of the manuscript Shidyāq consulted: Abū al-Dardā, Sa'd ibn 'Ubād, Harqūsh ibn Zayd, Sahl ibn Binhān, 'Uthmān ibn Mat'ūn, Dhuwāb ibn Hayr, Abū al-Hāliyah, 'Abd Allāh ibn 'Umar al-Qādị, and Abū Hudhayfah ibn 'Umar ibn Rabī'ah. The names of Abū Dharr, Khālid ibn al-Walīd, and 
Bilāl al-Habashī, which are found in the "Shidyāq Covenant" are missing from MS 358. The only name which exists in MS 358 but which is missing in the "Shidyāq Covenant" is 'Abd Allāh ibn Rawāhạh. The presence of Khālid ibn al-Walīd as a witness at an earlier date than his official conversion to Islām conforms with the letter to al-'Alā' ibn al-Hadramī which was written on 3 of Dhū al-Qada, 4 years after the Hijrah, and which "displays all of the scribal conventions found in the covenants" (El-Wakil 2019a, p. 7). When it comes to the witnesses to the Covenants of the Prophet, there is more than meets the eye.

\subsection{In the Footsteps of History: Tracing the Transmissions}

The Covenants of the Prophet are confirmed by the earliest Christian chronicles. In a chapter titled "The Rise of Islām, May Allāh Strengthen it and Make it Triumph," the author of the Chronicle of Seert, written at some point between the ninth and eleventh century, reproduced the "Covenant of the Prophet Muhammad with the Christians of Najrān" which had been in the possession of Habib, the Monk, who had obtained it from the Bayt al-Hikmah or House of Wisdom in 878/879, where he had worked as a curator prior to joining a monastic order (Scher 1907, p. 600/280). Just like the "Shidyāq Covenant," this covenant was also scribed by Mu'āwiyah, suggesting that it is perhaps the earliest copy made from an original "Covenant of the Prophet." In his Chronicum ecclesiasticum, Bar Hebraeus (1226-1286) provides us with more information about the "Najrān Covenant," attesting that:

Muhammad wrote to the bishop of the Banū al-Hārith, Banu Ka'b, and the bishops of Najrān and to their priests and monks: "There shall be guaranteed to you the protection of God and his apostle for the possession of your churches and your worship and your monasteries, and no bishop or priest or monk shall be molested ... so long as you remain true and fulfil your obligations." (Shed 1908, p. 103; Barhebraei 1877, pp. 117-18)

Although some scholars, like Addai Scher, have argued against the authenticity of the document, the privileges that the Prophet provided to the People of the Cross were cited centuries earlier. In his Universal History, written in 687 CE, "John of Phenek ... makes a clear mention of the fact that the Muslims had, from their leader Muhammad, a special order in favor of the Christians and the monks" (Mingana 1925, n. page). John of Phenek, also known as John Bar Penkaye, noted that:

[The Arabs] held ... an ordinance, stemming from the man who was their guide (mhadyana), concerning the people of the Christians and concerning the monastic station. Also as a result of this man's guidance they held to the worship of the One God, in accordance with the customs of ancient law [i.e., Old Testament]. At their beginnings they kept to the tradition of Muhammad, who was their instructor $\left(\operatorname{tar}^{\prime} a\right)$, to such an extent that they inflicted the death penalty on anyone who was seen to act brazenly against his laws (fol. 146a). (Mar-Emmanuel 2015, p. 15; Mingana 1908b, pp. 141, 175)

What is more, one of the oldest Islāmic inscriptions discovered to date was carved by Mu'âwiyah in the year 32 of the Hijrah and speaks of "the protection of Allāh and the security of His messenger (dhimmat Allāh wa damān rasūlihi)" (Zein and El-Wakil 2021, n. page). If Darīmī was correct, and the Bayt al-Hikmah was first founded by Mu'āwiyah as a repository for prophetic traditions (Balty-Guesdon 1992, p. 133), it seems reasonable that it contained a copy of the "Covenant of the Prophet" or various copies thereof. In fact, these foundational relics from the gestational period of Islām were transmitted from caliph to caliph, and dynasty to dynasty. It is therefore possible that the "Covenant of the Prophet" found in the Bayt al-Hikmah of Baghdad by Habib the Monk in 878/879 was the genuine article, namely, the copy made by Mu'àwiyah upon the dictation of Muhammad. The document would have been less than two-hundred years old.

It is well established that the Messenger of God engaged in different types of diplomacy, and his covenants with Christian communities align themselves to other diplomatic 
treaties such as the "Constitution of Madinnah," the "Treaty of al-Hudaybiyyah," and the "Treaty of Najrān." The verbiage and terminology employed in these and other treaties, which span over a thousand years from the earliest Islāmic and Christian sources pertaining to the origins of Islām until the final Ottoman sultan, support the claim of semantic continuity. The covenants that the caliphs, sultans, and shahs made with their Christian subjects show every indication of being modelled upon those of the Prophet Muhammad. They are the practical implementation of a Qur'ānic invitation to "come to common terms" with the People of the Book (3:64). They are a response to the Qur'ānic call to "co-operate in matters of righteousness and piety" (5:2). They are the embodiment of the Qur'annic empathy and amity found in the famous verse: "You will find nearest in affection to (Muslims) are those who say, 'We are Christians' since amongst them are priests and monks who are not arrogant. When they listen to that which was revealed to the Messenger, you will see their eyes fill with tears as they recognize its truth" (5:82).

In that context, it should be recalled that a cluster of communities transferred their allegiance from Byzantium to the Prophet Muhammad during the final years of his mission, including those of Aylah, Dūmat al-Jandal, Jarbā', Adhruh, and Maqnā. Arab historians relate how Yūhannah ibn Ru'bah, the Christian governor of Aylah, visited the Messenger of God in Tabūk (Abulmajd 2021, n. page). As Abdurrahman Abulmajd notes, "Brockelmann suggests that the Prophet Muhammad accepted the oath of allegiance of the Christian Prince of Aylah (now 'Aqabah) at the northeastern tip of the eastern arm of the Red Sea" (Abulmajd 2021, n. page). Christian, Muslim, and Jewish sources record that the Prophet Muhammad provided written privileges to the Jews of Maqnā and the Christians of Aylah (Abulmajd 2021). Since the Byzantines supposedly did nothing to prevent the Islāmization of the Arabs of the north, and repeatedly retreated from any confrontations with the troops commanded by the Messenger of God and his companions, Émile Dermenghem suspected that a secret treaty had been concluded between Heraclius and the Prophet Muhammad (Dermenghem 1930, p. 327). Still, as the historian Ibn Khaldūn reports, Yūhannah ibn Ru'bah was so committed to the "Covenant of the Prophet" that he was martyred for it, suggesting perhaps that there was no secret treaty. Ibn Khaldūn reports that when the Prophet reached Tabūk:

The people of Aylah, Jarbā', and Adhruh came to him and handed over the jizyah. The governor of Aylah at that time was Yūhannah ibn Ru'bah ibn Nufāthah, belonging to the tribe of Judhām, who gifted the Prophet a white mule ... He [i.e., the Prophet] remained in Tabūk for approximately 10 nights, after which he returned to Madinnah. News of Yūhannah reached Heraclius who commanded that he be killed and crucified in his town. (Ibn Khaldūn 1971, p. 224)

As Abulmajd explains, Yūhannah “continued to uphold Prophet Muhammad's covenant, thus setting the most remarkable example of true Christianity in adhering to covenants and oaths" (Abulmajd 2021, n. page). As Sidarouss Sésostris stated in Des patriarcats,

Le Livre Sacré des Mahométans prescrit ... le respect de la liberté religieuse et l'indépendance des peuples conquis ... Les édits du Prophète lui-même ne peuvent laisser de doute sur ce point; qu'on lise son édit à tous les hommes ainsi que son édit à Youhanna Ben Ro'yat et aux autres habitants de Aylat et l'on verra toute la sollicitude qu'il témoigne aux chrétiens ainsi que tout le souci qu'il a de mettre ses recommandations à l'abri de toute violation éventuelle. (Sésostris 1906, p. 151)

The holy book of the Muslims call for ... respect for religious liberty and the autonomy of conquered populations ... The edicts of the Prophet himself leave no doubt on this point. One only has to read his edict to all men as well as his edict to Yūhannah bin Ru'bah and to the other inhabitants of Aylah and one will see the care he shows for Christians and his concern to ensure that his recommendations remained safe from any eventual violation. 
Even if one accepts the allegations of critics, cynics, and skeptics that the Covenants of the Prophet were the subject of snowballing over the centuries, the historical chain of custody confirms that they contain elements of truth, namely, that Muhammad protected monks and Christians. The claim made by Jean-Michel Mouton and Andrei Popescu-Belis that the monks from Mount Sinai obtained a copy of the "Covenant of Najrān" from the Chronicle of Seert at some point in history, and appropriated it as their own, seems to have little merit (Morrow 2017, vol. 1, p. 388). By granting his covenant to the Monastery of St. Catherine, the Prophet was essentially granting a covenant to the entire world of Greek Orthodoxy. It is therefore far more conceivable that the monks of Mount Sinai received a separate copy of a covenant during the Prophet's lifetime. As Pascal noted in La Maison Royale de Lusignan,

Les maîtres d'Égypte n'ont pas cessé de montrer aux religieux du mont Sinaï une spéciale bienveillance, et les sultans de Constantinople, à leur avènement au trône, leur envoient des lettres de protection en souvenir de l'édit de Mahomet, par reconnaissance du bien qu'ils font aux tribus de la péninsule et aussi pour la vénération que les musulmans eux-mêmes portent aux saints lieux dont ces religieux ont la garde. (Pascal 1896, pp. 153-54)

[The rulers of Egypt have never ceased to show benevolence to the monks from Mount Sinai and the sultans of Constantinople, since their accession to the throne, send them letters of protection in memory of the Edict of Muhammad in recognition for the good they do to the tribes of the peninsula as well as an expression of the veneration that Muslims themselves show toward the holy sites that the monks protect.]

\subsection{Untangling the Modes of Transmission, Textual Variants, and Scribal Errors}

The "Aubert Covenant" is a copy of a document that was written down by 'Ali ibn $A b \overline{1}$ Ṭālib during the first days of Muharram of the second year of the Hijrah (Aubert 1938, p. 39). The "Coptic Covenant," which appears to have derived from it, is not dated, and wrongly refers to the scribe as Abā Ṭālib ibn Ahmad (Morrow 2017, vol. 2, pp. 235, 241). The "Coptic Covenant" contains many linguistic variants, including Egyptian colloquialisms, showing that conveying the content was more critical than reproducing words verbatim. Such problems of transmission are apparent with more manuscripts coming our way.

When I first began studying the Covenants of the Prophet, I assumed that the "Covenant with the Christians of the World" was an independent text to the "Covenant with the Christians of Najrān." My colleague Ahmed El-Wakil also initially supported that view but nevertheless came to question it in December 2017 when he was allowed by Father Tatul Anushyan to examine the "Covenant of the Prophet" housed in the Armenian Patriarchate of Constantinople in Istanbul. I myself have examined the manuscript and can vouchsafe his observations. Similarly to the "Covenant with the Christians of Najrān" which states that it was written "to al-Sayyid ibn al-Hārith ibn Ka'b and the people of his creed (li-lsayyid ibn al-Hārith ibn Ka'b wa ahl millatihi)," the copy in the Armenian Patriarchate of Constantinople reads rather awkwardly "wa katabahu al-Hārith ibn Ka'b li-ahl millah." Though both of these texts record $\mathrm{Mu}^{\prime}$ 'āwiyah as scribe, unlike the "Covenant with the Christians of Najrān" which does not provide us with a date, the copy in the Armenian Patriarchate of Constantinople states, again rather unadroitly, that it was written "on a Monday from the Prophet's Hijrah (yawm ithnayn min hijrah al-nabawiyyah).

The "Shidyāq Covenant" states in a similar fashion to the "Covenant with the Christians of Najrān" and the copy in the Armenian Patriarchate of Constantinople that "It was written to al-Hārith ibn Ka'b." If we assume that the date was mistakenly copied out in the manuscript consulted by Fāris al-Shidyāq, then this would entail that the correct date ought to have been "Monday, at the closing/end of Rabi' al-Ākhir, during the fourth year of the Hijrah." Consequently, as of 2021, Ibrahim Zein and Ahmed El-Wakil have changed their view regarding the genesis of the covenants. They both currently believe that the 
"Covenant with the Christians of the World" and the "Covenant with the Christians of Najrān" are at their origin one and the same document. In their view, the differences in the different recensions are all the result of transmission. In other words, scribes paraphrased, re-wrote certain clauses, did not copy the texts attentively enough, or were dealing with copies which had faint script-all leading to differences emerging in the process of transmission. As far as Ahmed El-Wakil is concerned, the presence of Mu'āwiyah's name posed a problem to later copyists who intuitively believed it was a mistake, and so preferred to omit it. This is why he believes that we find no date on the "Najrān Covenant" that is in the Chronicle of Seert. As for the "Covenant of the Prophet Muhammad with the Armenian Christians," they currently treat it as a separate document.

The "Najrān Covenant" could have reached different Christian communities over the course of history. Since it addressed "the Christians of the world," it is within the realm of possibility that various monasteries and denominations appropriated the document, resulting in minor variations in style, but never overtly changing the substance. One other possibility is that it became popular during the rule of $\mathrm{Mu}^{\prime}$ āwiyah who commissioned copies of it and ensured it was distributed to the various Christian provinces under Islāmic jurisdiction.

As theorized in The Covenants of the Prophet Muhammad with the Christians of the World, we are faced with two likely modes of transmission when it comes to the covenants (Morrow 2013, pp. 382-83). The first mode of transmission could be the outcome of multiple individual prophetic transmissions resulting from the Prophet having issued many covenants to Christians during his lifetime. I have postulated the possibility that the Prophet Muhammad provided covenants of protection to the major Christian denominations of his time. He would have provided covenants to the Christians of Najrān, Sinai, Assyria, Egypt, the Levant, Persia, and elsewhere, despite some of these being possible duplicates.

The second mode of transmission suggests a single source transmission, meaning that there was a Q-source covenant, namely, a prototype which was copied out during the Prophet's lifetime, became widely disseminated, and subsequently resulted in numerous textual variants. In other words, unlike the first mode of transmission which contends that the variances originated with the Prophet himself, the second mode of transmission proposes that the scribes themselves are largely the reason behind the variants when they consulted the Q-source covenant, with only a few stylistic divergences having occurred, and the date, the scribe's name, and the witnesses' names having been amended. This was the opinion of Ahmed El-Wakil when he proposed the theory of the "Master Template." If so, then it is possible that the Prophet produced a single major covenant which was copied by both 'Alī and Mu'āwiyah and which came to form two scribal lineages. The one attributed to 'Alī circulated in pro-'Alīd communities in Fātịmid Egypt, the Shī'ite Levant, and Safavid Persia while the one attributed to $\mathrm{Mu}^{\prime}$ 'âwiyah circulated in areas that had been controlled at some point by the Umayyads and other Sunnī dynasties. It is also possible that the scribes and witnesses were appended at a later point to provide the document with more religious weight.

In light of the fact that hundreds of letters attributed to the Messenger of God have survived in Muslim and Christian sources, not to mention half a dozen purportedly original ones, it seems plausible that he dispatched more than one covenant to Christian communities throughout the Middle East. How many copies he issued we do not know, and whether these were directly dictated by the Messenger of God or copied from a Master Template, is also difficult for us to tell. If we survey the scores of letters, treaties, and covenants, authentic or otherwise, found in Muhammad Hamīdullāh's (1908-2002) Majmū'at al-Wathā'iq al-Siyāsiyyah, 'Alī Ahmoadī Miyānjī's Makātīb al-Rasūl, and Hasan Shīrāzī's (1935-1980) Kalimat al-Rasūl al-A'zam, one would be hard pressed to claim that he only produced a single document destined to the Christians (Hamīdullāh 2001; Miyānjī 1998; Shīrāzì 1967). If so, such an action would be anomalous. Even if a fraction of the letters, treaties, and covenants that are ascribed to him are genuine, the Prophet produced a large body of correspondence. 
One possibility to explaining the widespread dissemination of covenants scribed by

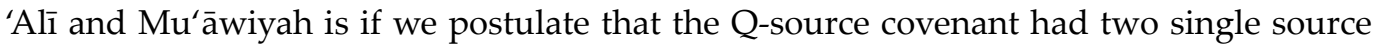
transmissions with bifurcation originating with these two scribal lineages. The bifurcation subsequently led to the link between the bifurcated version and the copy from which it was derived becoming difficult to establish because the language was reworked, and key elements came to be missing.

As an example, we may turn to the copies of the "Ashtīnāme" in the possession of the Sinai monks and other related communities which are relatively concise. Following private exchanges with Ibrahim Zein and Ahmed El-Wakil, it is clear that these stand in contrast to MS 695 which is said to have been copied in 1683/1684, but could also be earlier, and MS 961, both of which read very similarly to the version published by Jeanne Aubert in 1938 as Le Serment du Prophète and the copy that was discovered in the Bibliothèque Nationale de France and which was published as the Covenant of the Prophet Muhammad with the Christians of the World (1538) in 2013 (Morrow 2013, pp. 237-41, 247-53, 255-64). It is also highly similar to the "Covenant of the Prophet" recorded by Michel Gabriel in his book Tārīkh al-Kanīsah al-Antākiyyah al-Suryāniyyah al-Mārūniyyah, and which Louis Cheikho, the Jesuit Chaldean priest, orientalist, and theologian, was aware of (Gabriel 2012, pp. 588-94; Cheikho 1909, pp. 609-18 at 615, footnote 1; Morrow 2017, vol. 2, p. 546).

This potentially means that all the short versions of the "Sinai Covenant" are bifurcated transmissions of a longer version that read similarly to MSS 695 and 961. This would imply that all copies which have come down to us with 'Alī as scribe derive from one

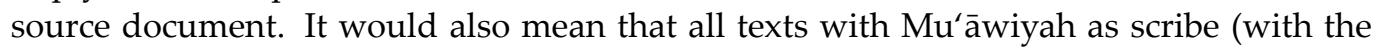
exception perhaps of the "Covenant with the Armenian Christians"), also derive from a source document, possibly the "Covenant with the Christians of Najrān" which bifurcated into the version found in Chronicle of Seert and the version that has popularly come to be known as the "Covenant with the Christians of the World" or Testamentum et pactiones (1630).

With time, there seems to have been a tendency to either capture, summarize, or synthesize the main clauses of the covenants. The "Shidyāq Covenant" not only has unique features shared with the covenants with the Christians of the world and Najrān, as well as the copy in the Armenian Patriarchate of Constantinople, suggesting that all of these originate with a covenant scribed by Mu'āwiyah, but like MS 696, the "Shidyāq Covenant" also commences with "In the name of Allāh, the Most Compassionate, the Merciful and with His Help," suggesting a potential connection to the "Sinai Covenant." This is further reinforced by a reference in MS AR 202 at the Hill Museum and Manuscript Library, also based on a manuscript scribed by 'Alī, that "it was written to al-Sayyid (katabahu li-lsayyid)," hinting to a potential connection between the 'Alī and Mu'āwiyah scribal lineages as both may have been addressed to "al-Sayyid," namely al-Sayyid ibn al-Hārith ibn Ka'b from Najrān (Ms. Ar 202, folio 155b).

Could both these scribal lineages have intertwined, with copyists having borrowed unique features from each one? This is a possibility. For example, Mkrtumyan records how one Armenian translation of a Persian manuscript lists the name of the scribe as 'Alī rather than $\mathrm{Mu}$ 'āwiyah "even though the date is Monday in the last day of the fourth month of the fourth year of the Hijrah" (Mkrtumyan 2021, n. page). Mkrtumyan also notes how an Armenian translation of the "Covenant with the Armenian Christians" from a Persian manuscript has not preserved the date of "Monday in the sacred month of Dhū al-Hijjah in the second year of the noble Hijrah," but rather has replaced it with "Monday in the last day of the fourth month of the fourth year of the Hijrah" (Mkrtumyan 2021, n. page). Despite the fact that we are dealing in the latter case with one scribal lineage, namely that of Mu'āwiyah, the observations made by Mkrtumyan indicate how at times copyists may have drawn on more than one covenant to reproduce their own textual recensions.

Though Fāris al-Shidyāq seems to have acknowledged that the document he had copied was based on a genuine copy of a prophetic covenant, he did not identify his primary source. Needless to say, the "Shidyāq Covenant" is consistent, in both style and substance, with the many surviving copies of the Covenants of the Prophet. The claim 
of tahrîf, in the sense of forgery, is untenable, a misreading, and a misinterpretation, for Shidyāq uses the verb harrafa to refer to poor copying on the part of the previous scribe. A similar observation was made by $\mathrm{Na}^{\prime}$ um Shuqayr regarding the copies of the covenants he had examined at the Monastery of St. Catherine and its dependency in Cairo, observing how many of the copyists were not native speakers of the Arabic language (Shuqayr 2018, p. 580).

The textual variants that we find form a natural part of the manuscript tradition. Scribes are human beings. They make mistakes. They also make corrections. At times, they improve upon the text for the purpose of clarity. They work with damaged fragments. It is normal for handwritten manuscripts to contain differences or textual variants. At times, scribes missed a line. At others, they copied the line twice. Although there were professional scribes, they could be costly. Some manuscripts were copied by scribes who had poor handwriting. The more a document is copied, the more it will produce textual variants. Far from a weakness, textual variants represent a strength. In the absence of an autograph, namely, an original handwritten copy produced by the author or his scribe, which in this case would be 'Alī and/or Mu'āwiyah, a large and diverse body of ancient copies serves to confirm the original content of the document.

The presence of variants is not necessarily an indication of untrustworthiness. Since the mistakes are not the same, the original can be ascertained by comparing the copies. Most of the mistakes are insignificant and can be dismissed. Others impact style and not substance, for example, the order of words or the use of synonyms. A small number of variants can alter the meaning; however, in most cases these are scribal mistakes or additions for the purpose of clarifications or commentary. Even when there are a few different clauses, they are not incompatible with Islāmic beliefs, laws, ethics, morals, and values. Since many of the manuscripts are dated, we can more or less identify which are the earliest versions and attempt to come to a close reconstruction of the original. Consequently, no content has been irretrievably lost. Fāris al-Shidyāq himself explained the corrections he had made when he reproduced the copy of the text. After all, as a professional scribe, he was outspokenly critical of other copyists, both past and present. As his alter ego complains in Leg Over Leg:

The country's ruler employed as scribes only those whose writing was ugly to the eye and whose words were disgusting to the taste ... this being a kind of public declaration that good fortune is not dependent on good handwriting, that to administer the law does not call for language without flaw ... and that they themselves have often attained lofty rank and exalted position though barely able to sign their noble names. (Shidyāq 2015, p. 38)

As for the "Shidyāq Covenant," a number of possibilities can explain its distinctive nature. For example, it could be a possible compendium or anthology drawn from many covenants, or possibly an expanded version of a more succinct original, where the implications of certain of the Prophet's decrees are more fully explained. It could also have been an attempt to reconcile various covenants to produce a standardized critical edition. Needless to say, this does not undermine its lineage from an original document scribed by $\mathrm{Mu}^{\prime}$ āwiyah.

\section{Authenticity and Historicity}

As can be appreciated, Fāris al-Shidyāq noted how the copyist who wrote down the "Covenant of the Prophet" had been sloppy. The claim, however, that the covenant traces back to the Prophet, grosso modo, in both spirit and form-with the understanding that the preservation and transmission of texts is subject to human fallibility and includes minor mistakes and variations - can indeed be verified to the best of academic and historical ability. Perhaps the most unique feature of the "Shidyāq Covenant" is that it bridges the gap between the "Covenant with the Christians of the World" and the "Covenant with the Christians of Najrān" in the Chronicle of Seert, suggesting that at their core both of these covenants were derived from an original covenant issued to the Christians of Najrān. 
While the details are up for debate, there is no reason to doubt that the Prophet Muhammad had an encounter with the Christians of Najrān and that he treated them with "magnanimity" (Hasanī and Malullāh 2019, p. 1617). As a tolerant and open-minded person, the Messenger of God "built an inter-religious linking bridge not a separating wall” (Santosa 2017 , p. 276) which contributed to creating a just society.

Critics like Fred Astren describe the "Najrān Covenant" from the Chronicle of Seert as a Gibeonite gambit, namely, a trick that was motivated by "dreams of integration" (Astren 2019, p. 25). He contends that it was concocted in response to oppressive Islāmic practices. In other words, Muslims oppressed Christians and Christians responded by fabricating covenants in an attempt to obtain greater rights and liberties. In so doing, they fabricated an imaginary past in which the Prophet Muhammad treated Christians with care. If the "Najrān Covenant" from the Chronicle of Seert is false, critics contend, then any other covenants that spawned from it are equally false. Rachel Hutchings, however, has shown that this premise is not true.

According to Hutchings' analysis, the genuine surrender agreements did not "impose burdensome restrictions on the lives of non-Muslims, generally leaving them to live in peace" (Hutchings 2020, p. 30). They were "generally minimalistic with respect to the restrictions imposed on conquered Muslims" (Hutchings 2020, p. 30). In response to demographic changes, she has demonstrated that Muslims became increasingly intolerant over time and, by 'Abbāsid times, were demanding that limitations be placed on the rights of Christians. Muslim jurists, working at the behest of political authorities, forged "ancient surrender" agreements, and "reintroduced" them, claiming that they had been lost (Hutchings 2020, pp. 31-33). They falsely attributed these restrictive treaties to 'Umar and the Prophet to give them greater authority and supported them with spurious hadith reports (Hutchings 2020, pp. 32-33; see also Morrow 2013, pp. 336-37). Since the Christians had broken their pledges, claimed the 'Abbāsid jurists, the authorities were justified in restricting and even removing some of their rights and freedoms (Hutchings 2020, pp. 32-33). This is precisely the scenario that I have proposed, that the tolerant treaties of the Prophet Muhammad, the four first caliphs, and their generals, are the genuine seventhcentury article whereas the intolerant ones are 'Abbāsid impostures from the eighth and ninth centuries. They follow in the political and philosophical footsteps of the "Covenant of Madīnah," "a brilliant idea which was to give recognition to the principles of universal humanity in a plural society" (Zainuddin 2019, p. 2100). As Craig Considine expresses,

In tandem with the Qur'ān, hadīths, and the Constitution of Medina, the covenants assure Christians that they will have the freedom to choose their spiritual destiny as citizens of the ummah. His inclusive position on incorporating Christians reflects this verse of the Qur'ān (3:64): "Say: O People of the Book, come to an equitable word between us and you" ([51], p. 83). Far from being a tyrant, as depicted in modern representations. Muhammad developed a democratic aptitude towards Christian communities. The Prophet's relationships with Christians can be characterized by more than mere tolerance, but rather by compassion and the fostering of peace. (Considine 2016, n. page)

The Christians did not forge covenants in response to Muslim oppression under the 'Abbāsids. They brought them out to protest the change in the status quo. It was not the Christians who had broken the promises they had made to the Prophet; it was the Muslim authorities. Additionally, since the bona fide Covenants of the Prophet did not align with restrictive 'Abbāsid policies, they fell out of circulation among many Muslims. They were no longer copied. They were conveniently ignored. They were destroyed. Since this seismic shift in the development of Islām coincides with the canonization of its sources, the Covenants of the Prophet, in their full and faithful form, were excluded from books of traditions, history, prophetic biography, and jurisprudence. It was tabula rasa. Additionally, when they were invoked, they were dismissed as forgeries. In fact, one could contend that the biographies of certain companions of the Prophet were changed by the traditionists and jurists to invalidate their presence as witnesses to the covenants. This 
includes altering the biographies of personalities like Mu'āwiyah ibn Abī Sufyān, Sa'd ibn

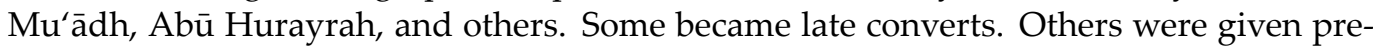
mature deaths. Yet others, who appeared as witnesses on ancient documents, were cast into oblivion. Even Astren admits that the rejection of the "Covenant of Khaybar" by alKhațīb al-Baghdādī (1002-1071), on the behest of his patron, the vizier Abū al-Qāsim ibn Muslim, was the product of anti-Shī'ite policy. As he recognizes,

Sunnī Muslims were forced to rewrite the history of Khaybar in order to harmonize Muhammad's assurances to its Jews with the later expulsion of Jews and Christians from the Hijāz that is ascribed to the caliph 'Umar (pp. 634-44). For Sunnis, the contradiction between authoritative precedent set forth by the Prophet and later caliphal policy led to the generation of ahädith that provide prophetic foreknowledge of this later development. In addition, Muhammad's settlement imposed upon the Jews of Khaybar was revised in order to demonstrate that the Prophet was explicit in indicating that its terms could be revoked. For the Shī'ite Ismā'îlī Fātimids, the first three caliphs were illegitimate usurpers who supplanted the rightful caliph, 'Alī ibn Abū Ṭālib ... Hence, al-Hākim's exemption of Khaybarī Jews constitutes an anti-Sunnī gesture that upholds Muhammad's prophetic authority against its later violation by 'Umar. (Astren 2019, p. 22)

For Astren, the Sunnīs were lying, the Shī'ites were lying, the Christians were lying, and the Jews were lying. This is reductio ad absurdum. At the same time, Astren admits that "in Muslim society of the Geniza era, Muhammad's letters of protection were understood to be authentic, and as such, could have legal standing" (Astren 2019, p. 20). As such, he notes that Jews and Christians have historically presented copies of prophetic covenants to authorities when requesting rights, releases, and exemptions (Astren 2019, p. 21). Astren has put certain parts of the jigsaw together; however, he has not completed the puzzle. 'Umar (pp. 634-44) purportedly expelled the Jews from Khaybar and the Christians from Najrān and forcibly relocated them in violation of the promises of the Prophet. Anyone who wishes to follow the alleged hardline of 'Umar would have to reject the covenants with the Jews of Khaybar and the Christians of Najrān as dubious. However, just like they forged a right-removing "Covenant of 'Umar," in an attempt to supplant the right-giving "Covenant of 'Umar" which aligns with the Covenants of the Prophet Muhammad with the Christians, it is possible that 'Umar did not, in fact, expel the Khaybarī Jews and Najrānī Christians. It is conceivable that these actions were projected back to 'Umar by some 'Abbāsid ruler to serve as a pretext and precedent. Although the accounts differ, the notion that there was a covenant of the Prophet with the Christians remained a constant. The question remains: was it coercive or compassionate? Was it oppressive or emancipating? Was it exclusive or inclusive?

If the Qur'ān describes Muhammad as a "beautiful example" (33:21), and a man of "sublime character" (68:4) who was sent as a "mercy to humankind" (21:107), then one would expect him to be the Qur'ān walking and the Qur'ān talking. It must, in my mind, have been a covenant of compassion from a messenger of mercy. This is not because I am a blind believer. On the contrary, I am extremely critical of certain sources. The Covenants of the Prophet are consonant with the Qur'ann. Consequently, I am inclined to believe that they are genuine in spirit, if not in form. Many other sources, however, including works of hadìth, tafsìr, sìrah, tarìkh, and figh, namely, prophetic traditions, Qur'ānic exegesis, prophetic biography, history, and jurisprudence, are discordant. Consequently, I am inclined to believe that they are bogus. This is not a faith-based approach or "pious" scholarship. It is a rational and rigorous academic methodology that pits me, and other scholars, against so-called "orthodoxy" and "tradition." Orthodoxy, however, is in the eye of the beholder. 


\section{The Source of the "Shidyāq Covenant"}

While this study was on the verge of being submitted for publication, providence put me on the trail of the "Covenant of the Prophet Muhammad" housed in the collection of the John Rylands Research Institute and Library at the University of Manchester in the United Kingdom. Thanks to a lead from Ibrahim Zein and Ahmed El-Wakil, who thought that the "Shidyāq" and "John Rylands Covenant" might be one and the same, I contacted UML Special Collections, Reader Services, and the Imaging Department, set up a visualizer session, identified the correct manuscript, and ordered a digital copy for private study. I was able to confirm that the "Shidyāq Covenant" was a copy of the following document described by C.E. Bosworth in A Catalog of Accessions to the Arabic Manuscripts in the John Rylands University Library:

819 [831]

A photographic copy of a covenant and agreement of the Prophet Muhammad addressed to Christians everywhere, ostensibly issued in Medina in Rabī ${ }^{\circ} 4 /$ September-October 625, and with the subscribed names of thirty-five witnesses from the Companions, beginning with Abū Bakr, Mu'āwiya b. Abī Sufyān and 'Abdallāh b. 'Abbās, and ending with Ka'b b. Mālik.

This is a copy of the celebrated alleged edict of the Prophet to all Christians, known from texts given by such Christian authors as the anonymous Nestorian chronicler of Si'irt (5th/11th century) and the Jacobite prelate and historian Abū 1-Faraj Bar Hebraeus (7th/13th century), and going back to Muhammad's treaty with the Christians of Najrān in South Arabia in the year 10/631-2 (on which see Muhammad Hamīdullāh, Majmū' at al-wathā'iq as-siyāsiyya li-l-'ahd an-nabawī wa-l-khilāfa ar-rāshida, 2nd. edn. [Cairo 1377/1958] p. 110 ff.)

Concerning this treaty with the Christians in general, Fattal writes that "Une immense fortune était reservé à ce document" [A great destiny was in store for this document]. Its scope became even broader, until it became "the Edict of the Prophet to all mankind," and various ecclesiastical institutions of the Eastern churches have claimed to possess the original. There can, of course, be no question of the authenticity of the treaty as it stands, supposedly written in the year 4 of the hijra, before the system of hijri dating had been introduced by the second Caliph 'Umar b. al-Khattâab, and from the hand of Mu'āwiya, son of the man who was at that time the implacable leader of the pagan opposition to Muhammad. See the exhaustive discussion of the document by A. Fattal, Le Status légal des non-musulmans en pays d'Islam (Fattal 1958), pp. $27 \mathrm{ff}$.

The provenance of this copy is unknown.

Begins:

$$
\text { هذا المحرر يو افق للكتاب الإلهي و الأمر النبوي في الألفاظ الطاهرة لتحقيق الحقائق المصطفوي }
$$

Ends:

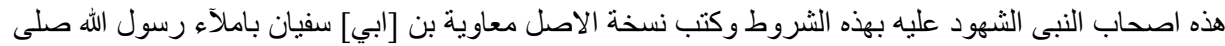

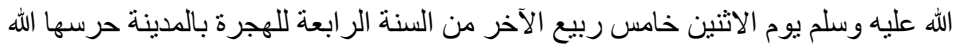

Modern binding by Bramhall and Menzies; 25 X 83 cm.; lines 1-46 in a rather careless but legible nashkhī hand, lines 47-67 in another, smaller hand with ruq'a features; red ink apparently used in the first section for the Prophet's name, and in the second section for the Prophet's name and some of the witnesses. (Bosworth 2017, pp. 36-38)

The manuscript numbers provided by Bosworth can cause confusion. It should be clarified that the "John Rylands Covenant" is not Arabic Manuscript 819 but rather Arabic Manuscript 831. It is stored in a case and, according to the staff member who handled it, appears to be written on hessian cloth, known also as burlap or jute. Three-fourths of the document is written in a large, elegant, curving, Arabic script. I see no reason why 
Bosworth would describe it as "careless." The final fourth is written in a smaller, more functional, Arabic script with sharper angles. The final product is clearly the work of two scribes.

As a close comparison confirms, the "Shidyāq Covenant" is a faithful copy of the "John Rylands Covenant." For some reason, however, Shidyāq did not copy the first and final sentences of the manuscript. The first sentence, which is missing, states as follows:

$$
\text { هذا المحرر يو افق للكتاب الإلهي والأمر النبوي في الألفاظ الطاهرة }
$$

This copy agrees with the divine writ and the prophetic command to realize chosen truths in its pure speech.

These references to the book of Allāh and the sunnah of the Prophet Muhammad suggest that the "John Rylands Covenant" was copied by a Muslim, unlike some Christian copies, like MS Arabe 214, which use the Christian calendar, and include references to the Messiah (Morrow 2013, pp. 241, 263). It is unclear why Shidyāq did not include this statement. The final sentences, which are absent from Shidyāq's copy, read:

$$
\text { تم هذا الكتاب. و الحمد لله رب العالمين وصلى الله على سيدنا محمد وآله أجمعين ختم الله بالخير إن شاء الله تعالى. }
$$

The end. Praise be to Allāh Lord of all the Worlds, and blessings be upon our master Muhammad and his entire family. Allāh has concluded this matter in a goodly manner, by the will of Allāh the Most High. Amen to the One who grants assistance.

It is possible that Shidyāq refrained from copying the last sentences due to their formulaic nature. They also happen to be quite small and somewhat difficult to read. Besides correcting grammar from time to time, he also improved the orthography when required. It should be stressed that the following segment- "It was written down from the original copy which was in the handwriting of Mu'āwiyah ibn Abī Sufyān. The copyist [al-nāsikh] distorted its text [harrafahu] and so its language cannot therefore be attributed to the Arabs of old, particularly to the Messenger of Allāh who by consensus was the most eloquent of creation" - does not form part of the "John Rylands Covenant." These are the words and critical opinion of Shidyāq. As his recension stands, one cannot distinguish between the content of the "John Rylands Covenant" and the comments made by Shidyāq. At first, I presumed that the words above were found in the covenant that Shidyāq had copied. The "Shidyāq Covenant" also indicates that:

$$
\text { وكتب نسخة الاصل معاوية بن ابي سفيان باملاًء رسول الله صلى الله عليه وسلم يوم الاثثين خامس ربيع الآخر من }
$$

The original copy was written down by Mu'āwiyah ibn Abī Sufyān as dictated by the Messenger of Allāh, may the peace and blessings of Allāh be upon him, on Monday, on the fifth of Rabi's al-Ākhir, in the fourth year of the Hijrah.

However, the "John Rylands Covenant" reads slightly differently:

$$
\text { وكتب نسخها معاوية بن سفيان بإملاء رسول الله صلى الله عليه وسلم يوم الإثنين خامس ربيع الآخر من سنة الربعة }
$$

The copy was written by Mū'āwiyah ibn Sufyān as dictated by the Messenger of Allāh, may the peace and blessings of Allāh be upon him, on Monday the fifth of Rabī' al-Ākhir in the fourth year of the Hijrah.

Shidyāq also corrected the common mistake we find in many manuscripts, namely the name "Mū'āwiyah ibn Sufyān" to "Mu'āwiyah ibn Ab̄̄ Sufyān." Although it was hoped that the source of the "Shidyāq Covenant" could provide insight into its origin and history of transmission, the provenance of the "John Rylands Covenant" is unknown. We have, for the moment, run into a dead end. The "John Rylands Covenant" may still have some secrets to share. Carbon dating of its material and ink could shed light on the approximate time it was produced. The mere visual examination of this impressive document, 
however, reveals much to the informed eye. It is, with little doubt, a document intended for public display. It shows every indication of being a standard copy of the "Covenant of the Prophet" that was issued to churches, monasteries, and patriarchates throughout the Ottoman empire, copies of which are found in Egypt, Syria, France, Germany, the United Kingdom, Greece, Turkey, Armenia, Iran, the United States, and elsewhere.

While some Christian scribes made copies of the Covenants of the Prophet, the vast majority of them appear to have been mass produced by Muslim scribes at the behest of the Ottoman sultans and distributed to Christian communities as official patents of protection and operating licenses. In fact, the dissemination of Covenants of the Prophet throughout the Muslim and Christian world, namely, the Middle East and Europe, was part and parcel of diplomatic efforts on the part of the Ottoman empire. From 1630 until the fall of the Ottoman empire, translations of the "Covenant of the Prophet Muhammad with the Christians" were widely shared among Western diplomats. As I note in The Messenger of Mercy,

The Covenants of the Prophet were required reading for European and American diplomats Alexandre de Miltitz, the former minister of the Prussian king to the Ottoman Empire, included a copy of the Covenant of the Prophet Muhammad with the Christians of the World in his Manuel des Consuls or Consular Manual which was published in 1838. Likewise, Edward A. Van Dyck, a consular clerk of the United States in Cairo, Egypt, included a translation and commentary of the Covenant of the Prophet in his Capitulations of the Ottoman Empire in 1881. The Covenants of the Prophet were still being discussed by American officials in the early twentieth century. G. Bie Ravndal, the American Consul General at Constantinople, wrote about it in The Origin of the Capitulations and of the Consular Institution, an official publication of the US government that was printed in 1921. (Morrow 2021, p. 135)

In fact, the Relazioni dell'impero ottomano nel Sec. XVI [Relations of the Ottoman Empire in the Sixteenth Century], a seventeenth century Italian manuscript, of which only one copy exists in Bibliotèque Nationale de France (Cote: italien 1286-1287, Ancienne cote: Harlay 247), includes Gabriel Sionita's Latin translation of the "Covenant of the Prophet" as an example of Ottoman diplomatic efforts. Works on French diplomacy, such as Négotiations de la France dans le Levant, routinely included the text of the "Covenant of the Prophet" in Latin or French (Charrière 1848, pp. lxv-lxix). The covenants of Prophet published by Father Pacifique Scaliger de Provins (1588-1648), Gabriel Sionita (1577-1648), and Antoine Vitré (1595-1674) were not Christian forgeries that they presented in an attempt to dupe the Muslim Ottomans into providing privileges to Christian minorities in their empire and to extend trading rights to European Christian nations.

Scaliger returned from the Levant with a covenant of the Prophet that was transmitted through Christian channels. I located it in the National Library of France, at the back of MS Arabe 214, and published it for the first time in 2013 (Morrow 2013, pp. 167-76, 247-53, 255-63). As for the "Covenant of the Prophet" published by Gabriel Sionita, it is a faithful copy of a scroll that was in the possession of Vitré, the royal publisher. It was probably granted to King Louis XIII (r. 1610-1643) by either Sultan Ahmed I (r. 1603-1617), Sultan Mustafa I (r. 1617-1618, 1622-1623), Sultan Osman II (1618-1622), or most likely by Sultan Murad IV (1623-1640) or one of his grand viziers. I have located the original scroll and several hand-written copies made by Vitré which were used to prepare the publication of Sionita's 1630 Arabic/Latin edition, the famous Testamentum et pactiones initae inter Mohmeden Apostolum Dei et Christianae fide cultores. This seminal scroll, which is set to be the subject of a subsequent study, is a standard Ottoman-issued covenant of the Prophet. The same can be said of the "John Rylands Covenant." This demonstrates how the Ottoman Muslims were engaged in goodwill diplomacy with European Christian authorities. They were proud to showcase the protections that the Prophet Muhammad had provided to Christian minorities and to show that they themselves were implementing them as part of their domestic and foreign policies. The Christians also reciprocated by bringing out the 
Covenants of the Prophet that were in their possession. It was not a zero-sum game. It was a win-win situation for Muslims and Christians.

The process of negotiating rights by relying upon prophetic precedents, authentic or imagined, depending on one's perspective, took place throughout Islāmic history. It also occurred during the time of the Tanzimat or Ottoman legal reforms which attempted to recalibrate relations between the Muslim State and its religious minorities. The "Shidyāq Covenant" was copied in 1857. This is significant as this took place one year after the Islahat Fermani of 1856 which guaranteed the status of all Ottoman subjects, regardless of their faith, while dissolving the jizyah poll tax. It is also significant that this was a controversial move in the eyes of Ottoman Christian subjects, many of whom suggested that this was not an advantage but rather a dangerous breakdown of their relationship with the State and the Muslim majority (Davison 1954). In fact, "[t]he ecclesiastical hierarchies that ruled the Christian millet's also opposed equality" as it would "decrease their authority and lighten their purses" (Davison 1954, p. 854). In short, "the doctrine of equality faced formidable opposition from Christians of the empire who were leaders in the churches and the nationalist movements" (Davison 1954, p. 844).

For some Christians, the millet or faith community system, which granted dhimmah or special rights and protections to the Peoples of the Book, but not complete equality, was superior to the increasingly secular system that was being introduced in the Ottoman Empire as a result of pressure from European powers. Despite its defects, the millet system "did not lead to any systematic persecution of Christians by Muslims, nor to any systematic oppression of Christians by the Ottoman government" (Davison 1954, p. 845). When this system broke down, the fears of the Christians was borne out in the massacres of Mount Lebanon and Damascus in 1860 as detailed by Mikhayil Mishaqa in Murder, Mayhem, Pillage, and Plunder: The History of Lebanon in the 18th and 19th Centuries (1800-1873) (Mishaqa 1988). Clearly, Shidyāq was concerned about the safety and future of the Christian community under Ottoman rule. This foreboding may have motivated the copying of the "Covenant of the Prophet" and perhaps his own conversion to Islām.

\section{Conclusions}

The rediscovery and renewed interest in the "Shidyāq/Rylands Covenant" are certain to arouse scholarly interest. For critics, it serves to confirm their conclusions that the Covenants of the Prophet with the Christians are crude and blatant forgeries, dubious documents of Christian provenance or concoctions of Muslim apologists that are rife with anachronisms and written in poor Arabic. In so doing, they invoke Ibn Qudāmah, Ibn Taymiyyah, and Muhammad Hamidullāh, as well as some Western authorities, to support their views. For supporters, however, the plethora of Covenants of the Prophet that circulated around the world, many of which have survived, confirms textual consistency, accuracy, integrity, and fidelity.

Whether one believes in them or not, the proliferation of the Covenants of the Prophet evidences their importance to diverse Muslim and Christian communities. The "Shidyāq Covenant" appeared in 1857, the "Covenant of "Ali" appeared in 1870, and the "Blunt Covenant" was published in 1882. The "Cheikho Covenant" arose in 1910 as did the Persian language recension of the "Covenant of the Prophet" that was published by George David Malech. The "Aubert Covenant" surfaced in 1938 and the "Arpee Covenant" was shared with the world in 1946. The Covenants of the Prophet, 'Ali, 'Umar, and others, appear to resurface during difficult times, periods of turmoil in which Christians are persecuted by Muslims.

For critics, this fact supports the claim of forgery. In other words, the Christians had a vested interest in invoking purported charters of the Prophet in an attempt to save their own skins. For supporters, this continuity of historical transmission supports the claim of authenticity. Either way, the Covenants of the Prophet served the interests of both communities. What is more, the fact that they are called upon in times of need does not mean that they did not exist before. When Christians were protected, there was no need to demand 
protection in the name of the Prophet Muhammad. When they were republished, it was because they were relevant and needed to be remembered.

While the chasm between opponents and supporters of the covenants may appear unbridgeable, and their differences irreconcilable, the situation is more nuanced than it seems. It is true that some Islāmophobic critics, who view Islām as inherently intolerant, treat the Covenants of the Prophet as spurious. Some authorities, both Muslim and non-Muslim, argue that they are authentic to the letter. Yet others adopt a more nuanced approach. They opine that the Prophet's covenants with the Christians are based on early documents, particularly the "Treaty of Najrān," which were expanded and to which other elements, including matters of taxation, were included.

As Gayane Mkrtumyan has acknowledged, "The similarities of content, language, and structure indicate" that the recensions of the covenants "were either derived or influenced from one or more source document issued by the Prophet" (Mkrtumyan 2021, n. page). What is more, "[t]he very fact that these were copied out, translated, issued, renewed, and acknowledged by Muslim authorities indicates their authoritativeness" (Mkrtumyan 2021, n. page). As Viorel Panaite notes, "Muhammad's covenants with nonMuslim communities, such as the 'ahd with Najrān ... became a blueprint for peace arrangements between the Ottomans and their tributaries" (Panaite 2019, p. 8).

In light of the above, our confidence in the historical transmission of the Covenants of the Prophet can be restored. Whether they are authentic or not, they have been transmitted consecutively through various routes since at least the ninth century, if not earlier. Additionally, rather than debunk the Covenants of the Prophet as relatively recent forgeries, dating from the sixteenth or seventeenth century, the "Shidyāq Covenant" serves to reinforce them. As far as supporters are concerned, it represents another link in a long chain of historical transmission. For them, the covenants are authentic in spirit and letter. For those who adopt a more nuanced approach, they were not created in toto. They were based on original treaties that were amplified. Although they were expanded by Christians in an attempt to maintain their rights and obtain new ones, critics acknowledge that they contain elements of truth. For such, the Covenants of the Prophet may not be original to the letter; however, they are partially authentic in spirit.

Undoubtedly, the Covenants of the Prophet remain intriguing historical documents that will elicit debate and discussion for decades and centuries to come as they have done for well over a thousand years already. What is more, if these documents are accepted by Muslims as authentic, either in word or in spirit, they can help counter and prevent radicalization, promote moderation, and help protect minorities. This helps explain why they have become a central touchstone in contemporary Muslim-Christian dialogue.

Funding: This research received no external funding.

Conflicts of Interest: The author declares no conflict of interest.

\section{Notes}

https://bina.bulac.fr/ARA/MS.ARA.44\#?c=0\&m=0\&s=0\&cv=7\&xywh=0\%2C-424\%2C4514\%2C4254 (accessed on 4 April 2021).

2 Additionally, see folio 132: https://bina.bulac.fr/ARA/MS.ARA.44\#?c=0\&m=0\&s=0\&cv=269\&xywh=-1\%2C-383\%2C4422\%2C41 67 (accessed on 4 April 2021).

3 https://gallica.bnf.fr/ark:/12148/btv1b531420726/f538.item (accessed on 4 April 2021).

4 Jeanne Aubert should not be confused with Jeanne Aubert (1900-1988), the daughter of a French aristocrat, who was a famous singer and actress, nor should she be conflated with Jeanne Aubert-Picard, who helped organize the Jeunesse Ouvrière Chrétienne a Catholic apostolic organization for young people in 1928 (Aubert 1990). As the preface to Le Serment de Mahomet states clearly, Jeanne Aubert was “originaire elle-même d'Égypte” (Aubert 1938, p. 5). She was clearly a Franco-Egyptian.

Should read: بكتابته

Should read: فصيحها

Should read: أعجميها:

Should read: قريبها

Should read: بعيدها 


\section{References}

\section{Primary Source}

Arabic Manuscript. 831. Covenant of Muhammad Addressed to Christians Everywhere, The John Rylands Research Institute and Library, University of Manchester.

MS Ar 202, Hill Museum and Manuscript Library, and Repository: Fondation Georges et Mathilde Salem. 2008. HMML Project Number GAMS 01004. Available online: https://w3id.org/vhmml/readingRoom/view/501561 (accessed on 10 April 2021).

Shidyāq, Ahṃad Fāris al-. 1857. Majmū' fawā'id. Paris: BULAC, nd. Available online: https://bina.bulac.fr/ARA/MS.ARA.44\#?c=0\&m $=0 \& \mathrm{~s}=0 \& \mathrm{cv}=0 \& x y w h=-1581 \% 2 \mathrm{C}-1 \% 2 \mathrm{C} 3755 \% 2 \mathrm{C} 3539$ and https://archive.org/details/MS.ARA.44 (accessed on 4 April 2021).

\section{Secondary Source}

Abū ‘Ubayd. 1989. Kitāl al-amwāl. Beirut and Cairo: Dār al-Shurūq.

Abū Yūsuf. 1979. Kitāb al-Kharāj. Beirut: Dār al-Ma'ārif.

Abulmajd, Abdalrahman. 2021. The Prophet Muhammad's Covenant with Yūhannah ibn Ru'bah and the Christians of Aylah. Religions 12: 450. Available online: https://www.mdpi.com/2077-1444/12/6/450 (accessed on 4 April 2021). [CrossRef]

Agius, Dionisius A. 1990. Arabic under Shidyāq in Malta, 1833-1848. Journal of Maltese Studies 19-20: 52-57. Available online: https:// www.um.edu.mt/library/oar/bitstream/123456789/29018/1/ARABIC\%20UNDER\%20SHIDYAQ\%20IN\%20MALTA\%201833-184 8.pdf (accessed on 4 April 2021).

Alwan, Mohammed B. 1970. Ahmmad Fāris Ash-Shidyāq and the West. Unpublished dissertation, Indiana University, Bloomington, Indiana.

Astren, Fred. 2019. The Gibeonite Gambit: Harrānians, Karaites, and Khaybarī Jews on the Margins of Medieval Islāmic Society. Journal of Medieval Worlds 1: 3-26. [CrossRef]

Aubert, Jeanne. 1938. Le Serment du Prophète. Paris: Geuthner.

Aubert, Jeanne. 1990. J.O.C., qu'as-tu Fait, de nos vies? Paris: De l'Atelier.

Avdall, Johannes. 1870. A Covenant of 'Alī, Fourth Caliph of Baghdad, Granting Certain Immunities and Privileges to the Armenian Nation. Journal of the Asiatic Society of Bengal 1-4: 60-64. Available online: http://www.globalarmenianheritage-adic.fr/0ab/b_ali firman.htm (accessed on 4 April 2021).

Balādhurī. 1987. Kitāb Futūh al-Buldān. Beirut: Mū'assasat al-Ma'ārif.

Balkhī, Muqātil b. Sulaymān al-. 2002. Tafsīr. Beirut: Dār Ihyā' al-Turāth, vol. 1.

Balty-Guesdon, Marie-Geneviève. 1992. Le Bayt al-Hikma de Baghdad. Arabica 39: 131-50. [CrossRef]

Barhebraei, Gregorii. 1877. Chronicum Ecclesiasticum. Edited by Joannes Baptista Abbeloos and Thomas Josephus Lamy. Paris: Maisoneuve, Leuven: Peeters, Available online: https://archive.org/details/BarHebraeusChroniconEcclesiasticumVol.3/page/n 60/mode/1up? view=theater (accessed on 4 April 2021). 
Blunt, William Scawen. 1882. The Future of Islām. London: Kegan Paul, Available online: https://archive.org/details/futureofIslam00b lunuoft/page/168/mode/2up (accessed on 4 April 2021).

Bosworth, Clifford Edmond. 2017. A Catalog of Accessions to the Arabic Manuscripts in the John Rylands University Library of Manchester. Bulletin of the John Rylands Library 56: 34-73. Available online: https://www.escholar.manchester.ac.uk/api/datastre am?publicationPid=uk-ac-man-scw:1m2102\&datastreamId=POST-PEER-REVIEW-PUBLISHERS-DOCUMENT.PDF (accessed on 4 April 2021). [CrossRef]

Charrière, Emest. 1848. Négotiations de la France dans le Levant. Paris: Imprimerie Nationale, vol. 1.

Cheikho, Louis. 1909. ‘Uhūd Nabī al-Islām wa al-Khulafā' al-Rāshidīn li al-Nasāāā. In Al-Machriq: Revue Catholique Orientale Mensuelle. Beirut: Imprimerie Catholique.

Considine, Craig. 2016. Religious Pluralism and Civic Rights in a 'Muslim Nation:' An Analysis of Prophet Muhammad's Covenants with Christians. Religions 7: 15. Available online: https://www.mdpi.com/2077-1444/7/2/15 (accessed on 4 April 2021). [CrossRef]

Considine, Craig. 2020. The Humanity of Muhammad: A Christian View. Clifton: Blue Dome Press.

Considine, Craig. 2021. People of the Book: Prophet Muhammad's Encounters with Christians. London: Hurst.

Davison, Roderic H. 1954. Turking Attitudes Concerning Christian-Muslim Equality in the Nineteenth Century. The American Historical Review 59: 844-64. Available online: https://psi424.cankaya.edu.tr/uploads/files/Davison,\%20Christian-Muslim\%20Equality \%20in\%2019th-C\%20(1954).pdf (accessed on 4 April 2021). [CrossRef]

Dermenghem, Émile. 1930. The Life of Mahomet. Translated by Arabella Yorke. London: Routledge.

El-Wakil, Ahmed. 2017. Searching for the Covenants: Identifying Authentic Documents of the Prophet Based on Scribal Conventions and Textual Analysis. Qatar: Hamad Bin Khalifa University, ProQuest Dissertations Publishing, Available online: https://www.proq uest.com/openview/ff8b0e67cd3b3ece80055d8fee33643b/1.pdf?pq-origsite=gscholar\&cbl=2026366 (accessed on 4 April 2021).

El-Wakil, Ahmed. 2019a. The Prophet's Letter to al-Alā' b. Al-Hadramī: An Assessment of Its Authenticity in Light of the Covenants and the Correspondence with the People of Yemen. Islām and Christian-Muslim Relations 30. Available online: https://wwwtandf online.com/doi/abs/10.1080/09596410.2018.1557934 (accessed on 4 April 2021). [CrossRef]

El-Wakil, Ahmed. 2019b. 'Whoever Harms a Dhimmī I Shall Be His Foe on the Day of Judgment:' An Investigation into an Authentic Prophetic Tradition and its Origins in the Covenants. Religions 10: 516. Available online: https://www.mdpi.com/2077-1444/10/ 9/516/htm (accessed on 4 April 2021). [CrossRef]

El-Wakil, Ahmed, and Walaa Nasrallah. 2017. The Prophet's Covenant with Armenian Christians: A Critical Edition Based on the Reconstructed Master Template. In Isläm and the People of the Book: Critical Studies on the Covenants of the Prophet. Edited by John Andrew Morrow. Newcastle upon Tyne: Cambridge Scholars Publishing.

Fattal, Antoine. 1958. Le Status légal des non-musulmans en pays d'Islam. Beirut: Imprimerie Catholique.

Gabriel, Michel. 2012. Tārīkh al-Kanīsah al-Anțākiyyah al-Suryāniyyah al-Mārūniyyah. Ba'abdah: al-Matba'ah al-Lubnāniyyah.

Hamīdullāh, Muhạmmad. 2001. Majmū'at al-Wathā'iq al-Siyāsiyyah li-l-'ahd al-nabawī wa-l-khīlafat al-rāshidah, 7th ed. Bayrūt: Dār al-Nafä'is.

Hasan̄i, Riyyād Hāshim Hādī al-, and Nidạl Muayyad Malullāh. 2019. The Prophet Muhammad's Tolerance toward the Christians of Najrān. College of Basic Education Researches Journal 15: 1617-40. Available online: https://www.iasj.net/iasj/article/171260 (accessed on 4 April 2021).

Hutchings, Rachel. 2020. Non-Muslim Integration into the Early Islāmic Caliphate through the Use of Surrender Agreements. Honors thesis, University of Arkansas, Fayetteville, NC, USA. Available online: https://scholarworks.uark.edu/cgi/viewcontent.cgi?arti cle $=1005 \&$ context=histuht (accessed on 4 April 2021).

Ibn Kathīr. 1988. Al-Bidāyah wa-l-nihāyah. Beirut: Dār al-Ma'ārif.

Ibn Khaldūn. 1971. Tārìkh. Beirut: Mū'assasat al-A'lāmī, vol. 2.

Ibn Sa'd. 1990. Al-Ṭabaqāt al-Kubrā. Beirut: Dār al-Kutub al-'Ilmiyyah, vol. 2.

Ibn Shabbah. 1979. Tārīkh al-Madīnah. Jeddah: al-Sayyid Habīb Ahmaad, vol. 2.

Mar-Emmanuel, Emmanuel Jospeh. 2015. The Book of Resh Melle by Yohannan Bar Penkaye: An Introduction to the Text and a Study of its Literary Genre. Ph.D. thesis, University of Toronto, Toronto, ON, USA.

Massé, Henri. J. Aubert. 1940. Le Serment du Prophète. Revue de l'histoire des religions 121: 196-98.

Mingana, Alphone. 1908a. Sources Syriaques. Leipzig: Otto Harrassowitz, vol. 1.

Mingana, Alphone. 1908b. Sources Syriaques. Leipzig: Otto Harrassowitz, vol. 2.

Mingana, Alphone. 1925. An Ancient Syriac Translation of the Kur'an Exhibiting New Verses and Variants. John Rylands Library Bulletin 9: 188-235. Available online: https://www.answeringIslam.info/Books/Mingana/Syriac/index.htm (accessed on 4 April 2021). [CrossRef]

Mishaqa, Mikhayil. 1988. Murder, Mayhem, Pillage, and Plunder: The History of Lebanon in the 18th and 19th Centuries (1800-1873). Albany: SUNY.

Miyānjī, 'Alī Ahṃadī. 1998. Makātīb al-Rasūl. Qum: Mu'assasat Dār al-Ḥadīth al-Thāqafiyyah. 
Mkrtumyan, Gayane. 2021. An Historical Evaluation of the Covenants of the Prophet Muhammad and 'Alī ibn Abī Ṭālib in the Matenadaran. Religions 12: 138. Available online: https://www.mdpi.com/2077-1444/12/2/138 (accessed on 4 April 2021). [CrossRef]

Morrow, John Andrew. 2013. The Covenants of the Prophet Muhammad with the Christians of His Time. Tacoma: Angelico Press and Sophia Perennis.

Morrow, John Andrew, ed. 2017. Islām and the People of the Book: Critical Studies on the Covenants of the Prophet. Newcastle upon Tyne: Cambridge Scholars Publishing, 3 vols.

Morrow, John Andrew. 2021. The Messenger of Mercy: The Covenants of Compassion from the Prophet of Pluralism. New Delhi: Sanbun Publishers.

Panaite, Viorel. 2019. Ottoman Law of War and Peace: The Ottoman Empire and Its Tribute-Payers from the North of the Danube. Leiden: Brill.

Pascal, Le Chanoine. 1896. Histoire de la Maison Royale de Lusignan. Paris: Léon Vanier.

Roper, Geoffrey. 1998. Aḥ̣mad Fāris al-Shidyāq and the Libraries of Europe and the Ottoman Empire. Libraries E Culture 33: 233-48. Available online: https://www.jstor.org/stable/25548637?seq=1 (accessed on 4 April 2021).

Roper, Geoffrey. 2004. Faris, Ahmad [Ahmad Fāris; formerly Faris ibn Yusuf al-Shidyaq] (1805/6-1887), author and translator I Oxford Dictionary of National Biography. In Oxford Dictionary of National Biography, online ed. Oxford: Oxford University Press. [CrossRef]

Santosa, Nyong Eka Teguh Iman. 2017. Foundations of the Society of Mercy: Trust, Justice, and Ethics. Advances in Social Science, Education and Humanities Researches (ASSEHR) 125: 274-78. Available online: https://www.researchgate.net/publication/3231792 77_Foundations_of_the_Society_of_Mercy_Trust_Justice_and_Ethics (accessed on 4 April 2021).

Scher, Addai. 1907. Histoire nestorienne inédite (Chronique de Séert). Patrologia Orientalis 4.3, 5.2, 7.2, 13.4. (Paris 1908, 1910, 1911, 1919). Available online: https://archive.org/details/ScherChronicleOfSeertcombined1/page/n525/mode/2up (accessed on 4 April 2021).

Sésostris, Sidarouss. 1906. Les Patriarcats dans l’Empire Ottoman et Spécialement en Égypte. Paris: A. Rousseau.

Shaybānī. 1975. al-Siyar al-Saghīr. Beirut: al-Dār al-Mutahịdah li al-Nashr.

Shed, William Ambrose. 1908. Islām and the Oriental Churches: Their Historical Relations. New York: Young People's Missionary Movement.

Shidyāq, Ahmad Fāris al-. 2015. Leg Over Leg: Volumes One and Two. New York and London: New York University Press.

Shīrāzī, Hasan. 1967. Kalimat al-Rasūl al-a'zam. Bayrūt: Dār Ṣādir.

Shuqayr, Na'ūm. 2018. Tārīkh Sīnā wa-l-'Arab. Windsor: Hindāwī.

Sionita, Gabriel. 1630. Testamentum et Pactiones. Paris: Antoine Vitré.

Tabarī, Muhạmmad. 1969. Tarīkh Ṭabarī: Tarīkh al-rusul wa-l-mulūk. Cairo: Dār al-Ma'arif.

Vincent, A. J. 1939. Aubert, Le Serment du Prophète, 1938. Revue des Sciences Religieuses 19: 410-11.

Zainuddin, M. 2019. Islām-Christian Relations in Indonesia. Pertanika Journal of Social Sciences E Humanities 27: 2099-107. Available online: http://repository.uin-malang.ac.id/4966/3/4966.pdf (accessed on 4 April 2021).

Zarra-Nezhad, Mansour. 2014. A Brief History of Money in Islām and Estimating the Value of Dirham and Dinar. Review of Islāmic Economics 8: 51-65. Available online: https:/www.researchgate.net/publication/235761489ABriefHistoryofMoneyinIslamandEsti mamatingValueofDirhamandDinar\#: \{\}:text=It\%20finds\%20that\%20a\%20dinar, riyals\%20or\%20USD\%2032.5\%2D36.5 (accessed on 4 April 2021).

Zein, Ibrahim, and Ahmed El-Wakil. 2021. On the Origins of the Hijrī Calendar: A Multi-Faceted Perspective Based on the Covenants of the Prophet and Specific Date Verification. Religions 12: 42. Available online: https://www.mdpi.com/2077-1444/12/1/42/htm (accessed on 4 April 2021). [CrossRef] 